IMF Country Reports $\quad 18 / 190$

\title{
Union of the Comoros
}




\title{
INTERNATIONAL MONETARY FUND
}

IMF Country Report No. 18/190

\section{UNION OF THE COMOROS}

\section{SELECTED ISSUES}

This paper on the Union of the Comoros was prepared by a staff team of the International Monetary Fund as background documentation for the periodic consultation with the member country. It is based on the information available at the time it was completed on May 30, 2018.

\author{
Copies of this report are available to the public from \\ International Monetary Fund • Publication Services \\ PO Box 92780 • Washington, D.C. 20090 \\ Telephone: (202) 623-7430 • Fax: (202) 623-7201 \\ E-mail: publications@imf.org Web: http://www.imf.org \\ Price: $\$ 18.00$ per printed copy
}

\section{International Monetary Fund Washington, D.C.}




\section{INTERNATIONAL MONETARY FUND}

\section{UNION OF THE COMOROS}

\section{SELECTED ISSUES}

May 25, 2018

\author{
Approved By \\ African Department
}

Prepared by Ibrahim Ahamada, Mounir Bari, Mokhtar Benlamine, Michel Bua, Liam O'Sullivan, Cameron McLoughlin (all AFR).

\section{CONTENTS}

WEAK DOMESTIC REVENUE AND VOLATILE WINDFALL REVENUES

A. Introduction $\underline{4}$

B. Fiscal Policy Implementation in Comoros-Stylized Facts $\underline{4}$

C. Policy Recommendation for Suatainably Improving Revenue Mobilization in Comoros $\underline{10}$

D. Conclusion 13

Reference 15

\section{FIGURES}

1. Fiscal Policy Implementation in Comoros ___

2. Revenue Structure in 2017

3. Tax Revenue in Small States (2008-2017) ___ _ _

4. Tax Structure in Small States (2015-2017) ___

5. Improving Revenue Mobilization in the Context of Volatile Revenues____ $\underline{8}$

6. Compensation of Public Employees (2013-2017) ___ _

7. Tax Revenues in Liberia____ 11

8. Tax Reform in Georgia____

9. Foreign Direct Investment (FDI) in Georgia ___

\section{TABLES}

1. Comparison with Small States of Average Tax Structure 2008-2017___

2. Key Tax System Indicators in Georgia __

INFORMALITY AND GENDER INEQUALITY IN COMOROS ___ $\underline{\mathbf{1 6}}$

A. Introduction ___ $\frac{16}{17}$

B. Informal Employement in Comoros and SSA___

C. Gender, Informal Employment and Income Inequality: Preliminary Findings __ $\underline{\underline{20}}$

D. The Role of Informal Production Units in Comoros ___ 21 


\section{FIGURES}

1. Labor Force, Female $\underline{17}$

2. Share of Informal Employment in Total Employment $\frac{18}{18}$

3. Share of Informal Employment in Non-Agriculture $\frac{18}{19}$

4. Male to Female Ratio in Formal and Informal Employment ___

5. Male to Female Ratio in Formal and Informal Employment Non-Agriculture __

6. Female Participation in Labor Force __ $2 \underline{20}$

7. Gender Inequality and Income Inequality ___ _

8. Employment in Comoros, 2013

9. Informal Production Units (IPU) Creation by the Chief Gender____

10. Geographical and Sectoral Repartition of IPUs in Comoros____

11. Reasons for IPU Non-Compliance in Comoros_____

12. Impact of Reducing Inequality in Comoros ___

\section{TABLE}

1. Compliance with Regulations 23

MODERNIZING THE MONETARY POLICY FRAMEWORK IN COMOROS

A. Introduction $\frac{27}{28}$

B. The Existing Monetary Policy Framework. $\frac{28}{29}$

C. The Proposal to Modernize the Monetary Policy Framework ___ $\underline{29}$

D. Sequencing Reforms and Preconditions for BCC Bill Issuance ____

E. Conclusions ___ 33

References ____ 34

\section{FIGURES}

1. Required Deposits and Excess Deposits ___

2. Private Sector Credit Growth Compared to Other Monetary Aggregates ___ 29

3. Excess Reserves in Percent of GDP ___

\section{TABLE}

1. Implementation Steps for Modernization of the Monetary Policy Framework __ $\underline{31}$

FINANCIAL SECTOR RISIKS AND MONETARY POLICY EFFECTIVENESS ___

A. Background and Macroeconomic Context ___ $\frac{35}{36}$

B. Stylized Facts_Financial Sector Fragility and Risks ___ $\underline{36}$

C. Financial Sector Health and Monetary Policy ___

D. Conclusions and Policy Recommendations ___ _ 


\section{FIGURES}

1. Macroeconomic Developments ___

2. Financial Sector Developments___

3. Selected Financial Soundness Indicators ____

4. Non-Performing Loans and Provisions ___ 3

5. Lending and Non-Performing Loans by Industry Category _____

6. Cross-Country Comparison of Selected Financial Soundness Indicators $2016 \_\underline{40}$

7. Fianncial System and Interest Rates___

TABLE

1. FSI Heatmap 2017

ANNEX I

1. Interest Rates in the Comorian Economy 


\section{WEAK DOMESTIC REVENUE AND VOLATILE WINDFALL REVENUES ${ }^{1}$}

For many years now, Comoros' significant fiscal challenges have included weak revenues, a reliance on volatile one-off revenues, an increasing lack of budgetary realism leading to poor and declining budget execution rates. This chapter analyses Comoros' fiscal challenges through the lens of weak domestic revenues that have increased reliance on volatile windfall revenues and served as a handbrake on achieving Comoros' development goals through limiting investment budget execution. Based on crosscountry experience, concrete solutions and guidance for improving domestic revenues are presented.

\section{A. Introduction}

\section{Fiscal policy implementation continues to be very challenging in Comoros, with} unrealistic budgeting in the context of Comoros' development ambitions further undermining budgetary credibility (Figure 1). In March 2017, the Comorian authorities announced an ambitious goal to become an emerging market economy by 2030. This development goal was to be supported by a budget that foresaw a near-doubling of revenues and a more-than-doubling of capital expenditures. Despite a substantial improvement in revenue levels in 2017, in the order of 2.5 percentage points of GDP, both revenue and expenditure execution worsened in 2017 vis-à-vis stillunrealistic supplementary budget targets. ${ }^{2}$ This was due to the fact that (i) the supplementary budget revenue and expenditure targets, although lower than those foreseen by the initial budget law, remained highly unrealistic in view of Comoros' fragile budget execution capacity, and (ii) cash revenues were insufficient to meet cash expenditure needs, even though investment expenditures had been curtailed to adjust for the revenue shortfall. The latter gap between cash revenues and expenses was met by external financial flows in the order of about 5 percent of GDP (budget support and grants, drawing on the counterpart of SDR holdings ${ }^{3}$ and borrowing from an external financial institution). But the lack of budgetary realism further eroded budgetary credibility in 2017, making donor support more difficult, thus undermining foreign-financed project execution.

\footnotetext{
${ }^{1}$ Prepared by Ibrahim Ahamada, Mounir Bari, Mokhtar Benlamine, Michel Bua and Cameron McLoughlin. This chapter has benefited from comments from several IMF colleagues.

2 Relative to the 2016 outturn, the 2017 supplementary budget law, passed in October of that year, envisioned a oneand-a-half-fold increase in revenues, to KMF 64.4bn (23 percent of GDP); a two-and-a-half-fold increase in domestically-financed investment expenditure, to KMF 18.4bn (6.5 percent of GDP); and a doubling in foreignfinanced investment expenditures, to KMF 39.3bn (13.9 percent of GDP). Expenditure execution was worse than that of revenues, implying an unbudgeted-for overall cash surplus for the year (0.4 percent of GDP, versus a budgeted-for cash deficit of 1.3 percent of GDP).

${ }^{3}$ In Comoros, the central bank (BCC) acts as the fiscal agency for the government in relation to the country's SDR allocation. The Comorian government utilized its SDR allocation for budgetary purposes through credit from the BCC to the central government (the counterpart to the SDR allocation). On the BCC balance sheet, it was reflected as an increase in Treasury's liabilities to the central bank and on the asset side of the BCC as a claim on the Treasury.
} 


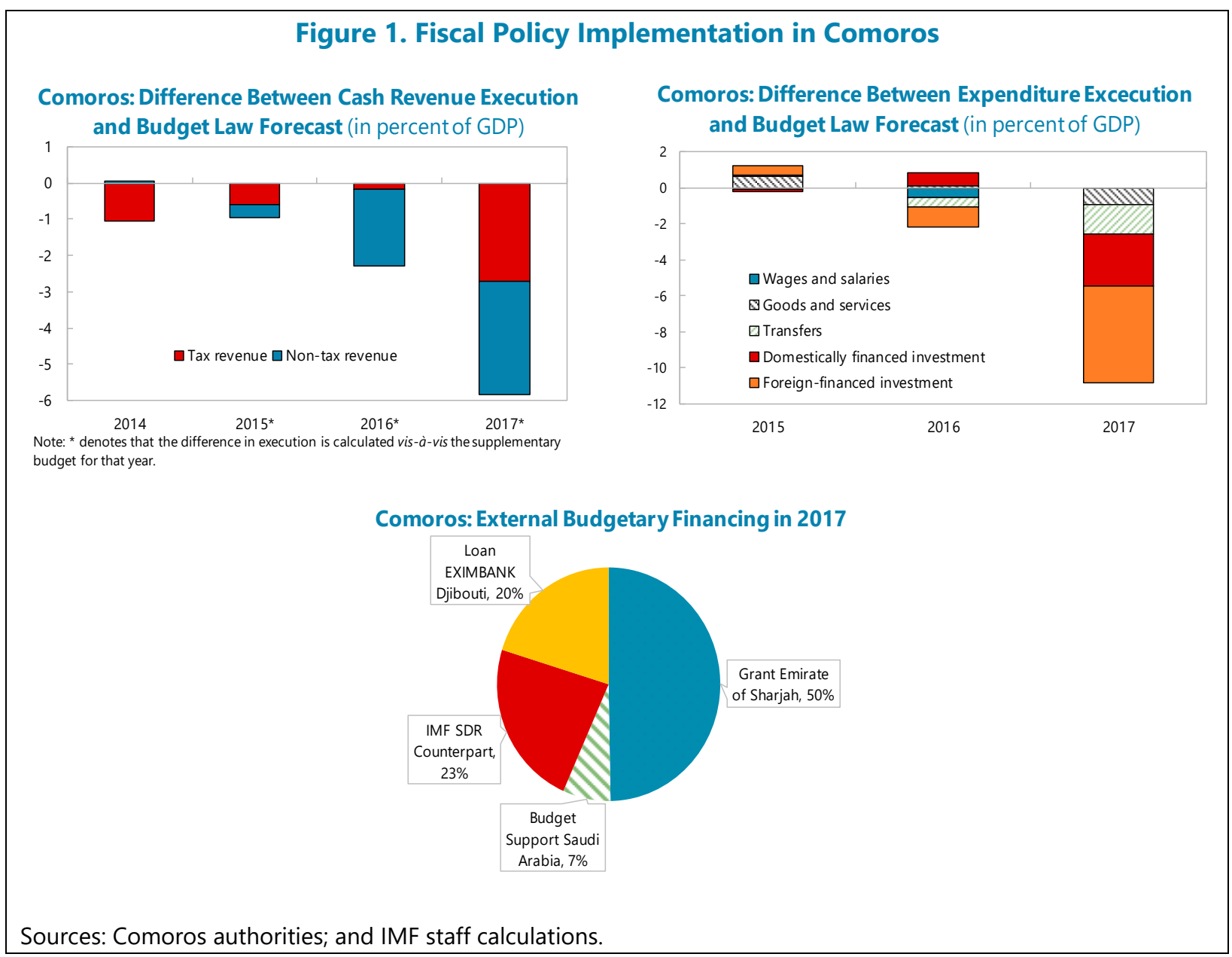

2. Boosting revenue mobilization in Comoros is important, as it tends to be a more growth-friendly means of assuring viability of the public finances, compared to cutting public spending, and would also provide space to attend to Comoros' significant development needs. Fiscal multiplier analysis for a sample of 35 SSA countries over the period 1990-2016 suggests that changes in government revenue had limited effects on growth. In contrast, unanticipated shocks to public investment and consumption expenditures tended to have large and significant effects on economic growth in SSA (SSA REO 2018). Improving revenue mobilization is thus an appropriate means for assuring the medium-term viability of the public finances, while attending also to Comoros' large development needs and addressing recent declines in living standards.

3. Against this background, this paper addresses two key issues. First, the chapter highlights some key stylized facts regarding fiscal policy implementation in Comoros, and updates previous work on Fiscal Trends in Comoros (see Country Report 16/394). Second, we draw on crosscountry experience to develop policy recommendations for improving revenue mobilization in Comoros. The latter is an essential element for financing the authorities' ambitious development strategy which, despite recent improvements, remains an important challenge faced by the Comorian authorities. 


\section{B. Fiscal Policy Implementation in Comoros-Stylized Facts}

4. Unlike in other countries, the budgetary framework in Comoros is largely disconnected from economic assumptions. In many countries, external economic factors (world growth, exchange rate, commodity prices) significantly impact tax revenue volatility. In Comoros however, the impact of these factors on revenue forecasts and execution is limited. There is a strong correlation between imports and customs revenues (the main source of tax revenues, Figure 2), however imports are highly dependent on volatile external financial flows (e.g. remittances and foreignfinanced capital expenditures).

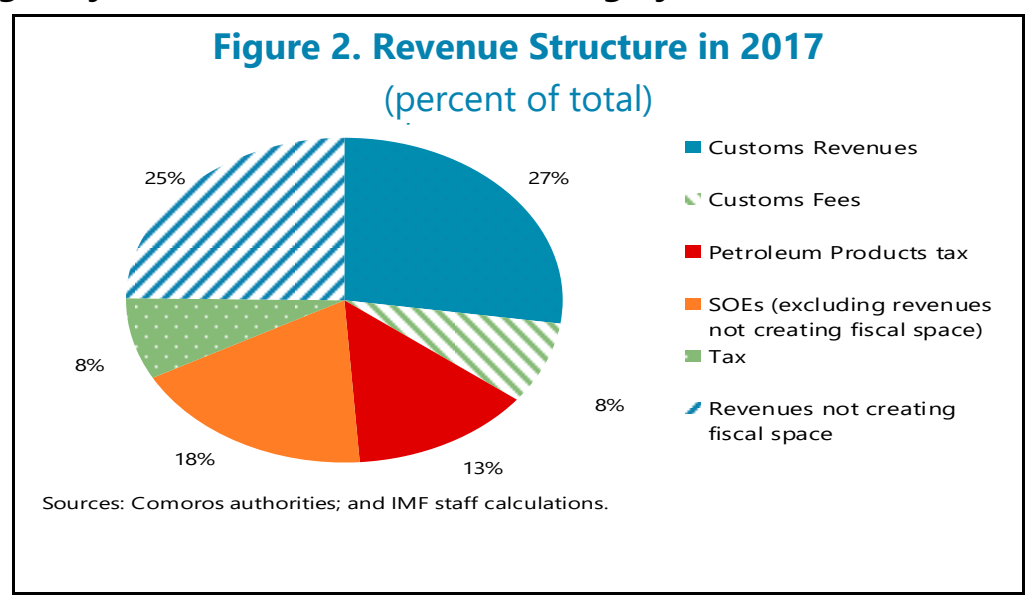

\section{Although revenues were much improved in 2017, historically speaking Comoros' tax} revenue to GDP ratio has remained well below the average small-states' performance (20082017). ${ }^{4}$ Tax revenues increased by an impressive 2.5 percentage points of GDP in 2017. But Comoros' average performance over the period 2008 - 2017 was well below that off all small states bar one (Figure 3). Comoros is also a belowaverage performer on individual components of taxation. Moreover, A tax revenue structure comparison (Table 1) over the period 2015-2017 indicates that Comoros records lower levels than the small states average in all categories. The largest gap between the small states average and Comoros' performance is in 'taxes on income, profits, and capital gains', with a

Figure 3. Tax Revenues in Small States (2008-2017)

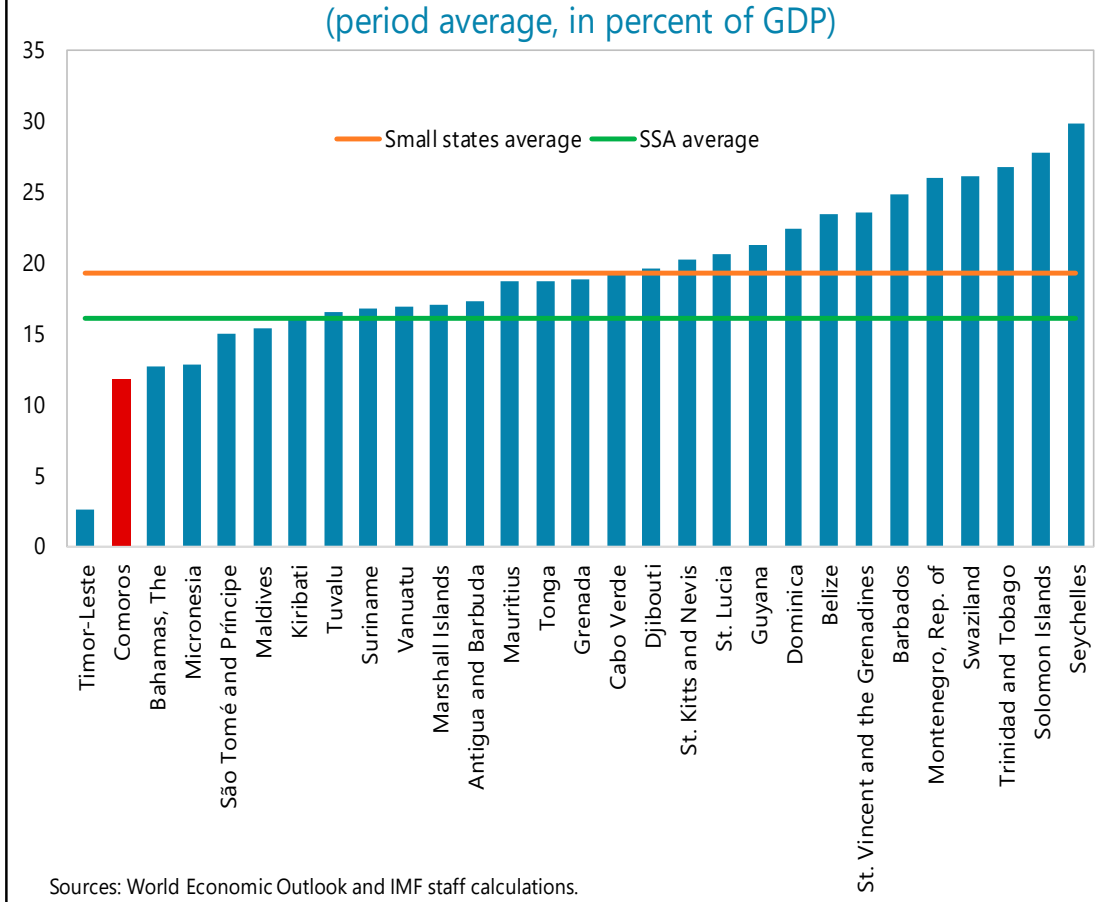
gap of 3.8 percentage points of GDP.

\footnotetext{
${ }^{4}$ Small States are defined as countries with population under 1.5 million.
} 
Table 1. Comoros: Comparison with Small States of Average Tax Structure, 2008 - 2017

(in percent of GDP)

\begin{tabular}{|c|c|c|c|c|c|}
\hline & $\begin{array}{c}\text { Small - States } \\
\text { Average }\end{array}$ & Seychelles & Cabo Verde & Mauritius & Comoros \\
\hline Taxes on goods and services & 8.5 & 16.1 & 9.3 & 11.8 & 7.7 \\
\hline Taxes on income, profits, and capital gains & 6.6 & 10.8 & 6.3 & 6.1 & 2.8 \\
\hline Taxes on international trade and transactions & 4.6 & 1.7 & 4.1 & 0.3 & 1.6 \\
\hline Taxes, not elsewhere classified & 1.4 & 3.3 & 0.4 & 1.6 & 0.1 \\
\hline
\end{tabular}

Source: IMF staff calculations

6. The highly-concentrated nature of taxation revenue in Comoros places a higher tax burden on existing taxpayers in the revenue base (Figure 4). In Comoros, tax revenues are more highly concentrated in taxes on goods and services (62.5 percent of taxation revenues, versus the small states average of 40.3 percent). Also, in Comoros, corporate taxes are dominated by stateowned enterprise (SOE) contributions, particularly that of the public telecoms utility (more than 65 percent of total corporate taxes over the last eight years).

Civil servants contributed 60 percent of all income taxes over the same period. In contrast, Comorian informal production units, which made up 79.2 percent of employment in Comoros in 2013, operate almost

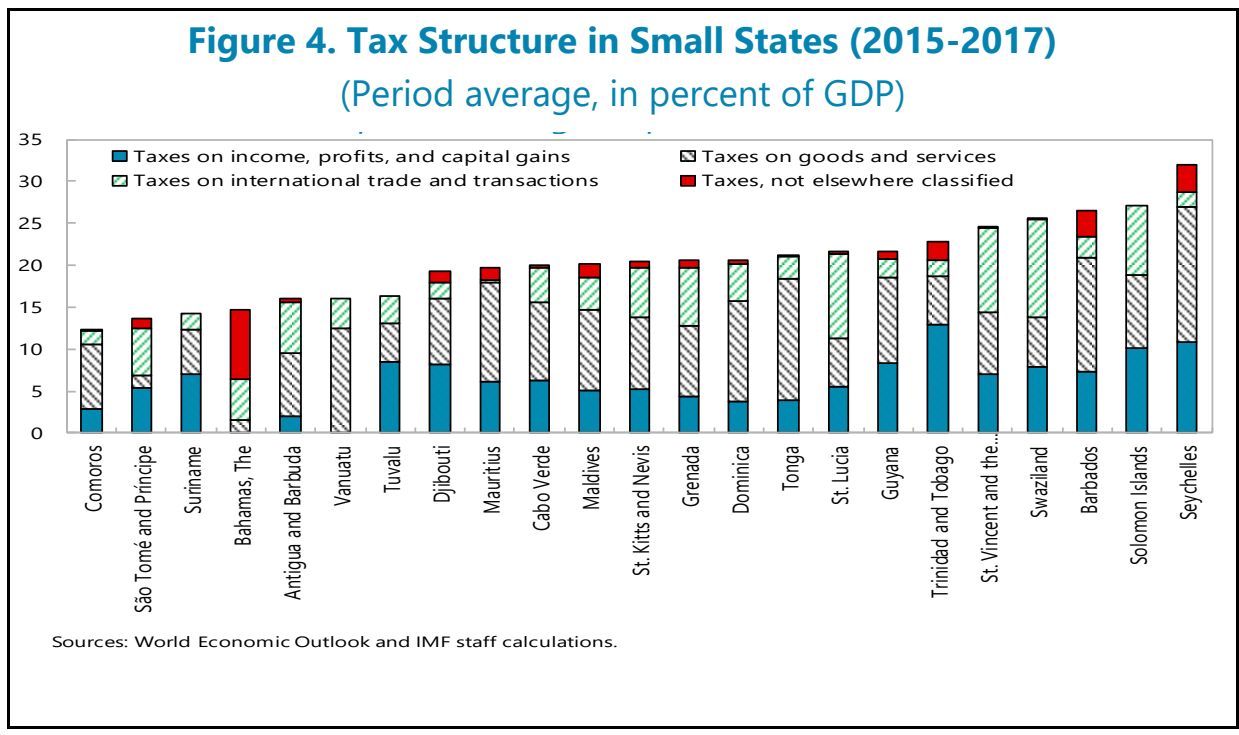
completely outside the taxation system with a tax ID number compliance share lower than 6 percent. improving the low rate of tax compliance could contribute significantly to improving the tax base in Comoros (see Selected Issues chapter on Informality and Gender Inequality in Comoros).

\section{Comoros' relatively volatile tax revenue level has not increased much over time,} especially compared to other regions, due partly to Comoros' low development level and a complex tax system (Figure 5). Comoros' tax ratio has tended to exhibit greater volatility than the SSA average. While the tax revenue level is what may be expected from a country at Comoros' development level, the relatively complex tax system makes paying taxes more difficult, hindering revenue mobilization efforts. Therefore, recent increases in Comoros' tax ratio have not been as marked as in comparator countries. 
Figure 5. Improving Revenue Mobilization in the Context of Volatile Revenues

Comoros lags its peers in tax revenue mobilization...

Tax revenue in Percent of GDP (1990-2017)

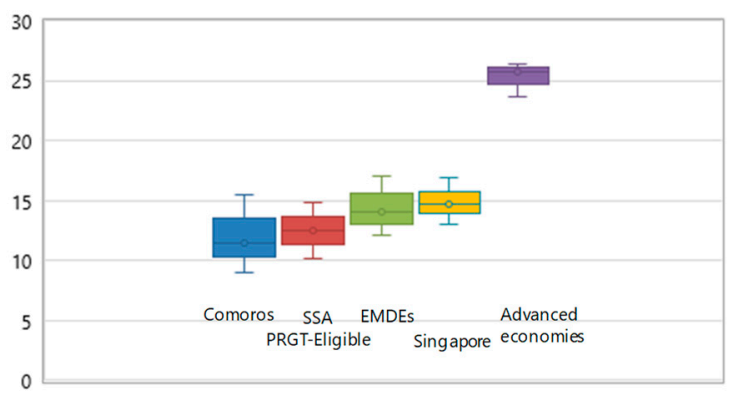

Part of this lower tax revenue is attributable to its low development level...

Tax Revenue and GDP per Capita in Emerging and Developing Economies, 2017

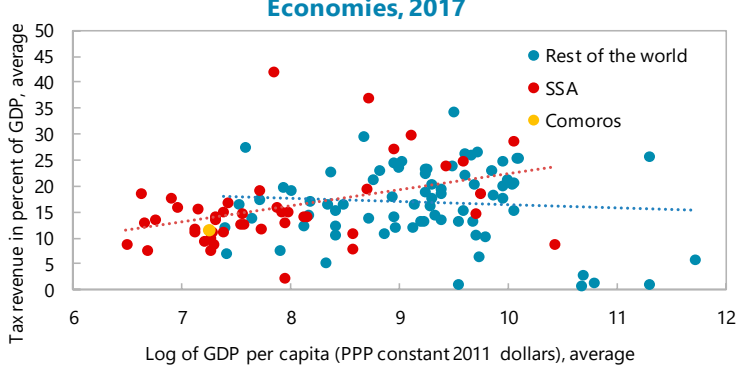

Tax buoyancy is not clear-cut in SSA...

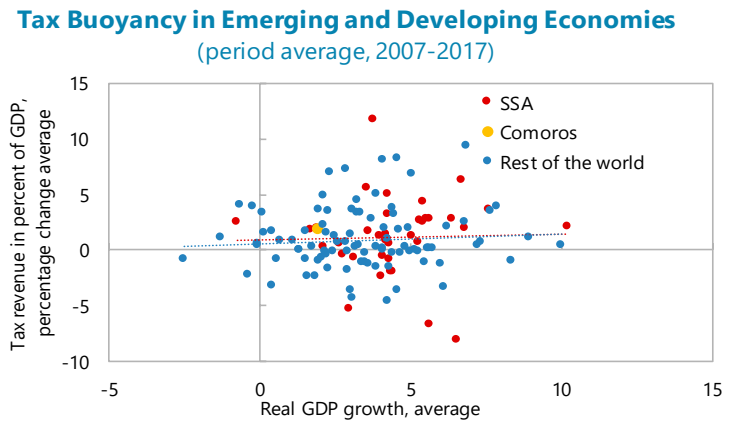

....and exhibits greater volatility relative to its SSA peers.

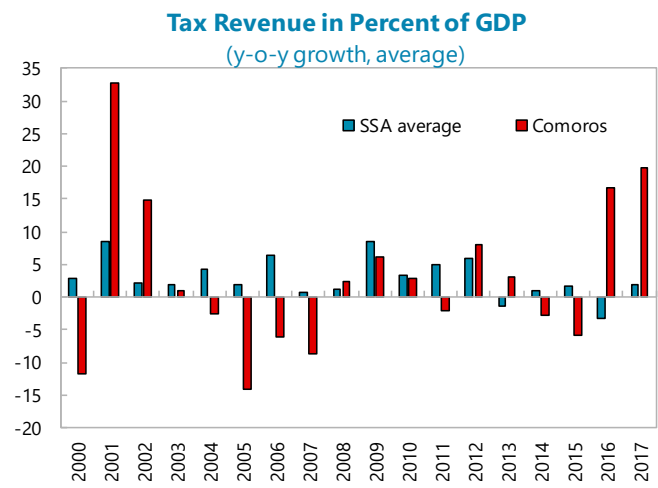

... and complex tax system that hinders its business climate.

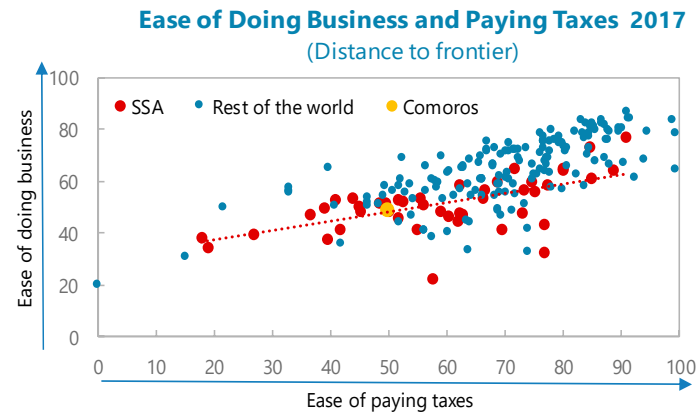

...reflected in a weak tax revenue increase over time, relative to other regions

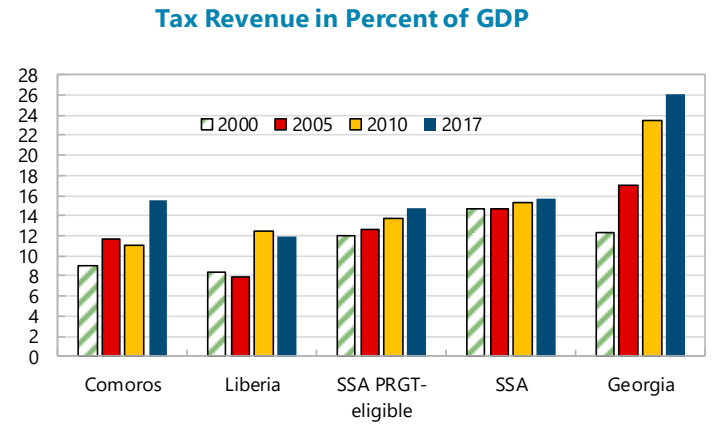

Sources: World Bank, World Development Indicators; WEO, and IMF staff calculations.

Note: EMDEs refers to Emerging Markets and Developing Economies. 
8. One-off windfall gains may be a welcome boon to the public finances, but raise difficulties for effective budgeting. In recent years, Comoros benefited from sizable one-off windfall gains. These included bilateral budget support (e.g. 7.5 percent of GDP from Saudi Arabia at end-2015, and 3 percent of GDP from Saudi Arabia and the Emirate of Sharjah in 2017), as well as revenue from the Economic Citizenship program. But these revenue streams may prove to be a double-edged sword. On the one hand, they may, if used wisely, provide welcome fiscal relief. However, on the other hand, they are highly volatile, more so than on average in small states. ${ }^{5}$ To the extent to which Comoros relies on these uncertain revenue flows affects budgetary credibility, increases the volatility of revenues and grants, and renders effective short-to medium term budgetary planning difficult.

\section{In Comoros, the wage bill takes up a large share of domestic revenues, leaving few} resources left over to attend to development needs. The wage bill in Comoros, measured as a percentage of domestic revenues, averaged 71.7 percent between 2013 and 2017. This was the fifthhighest of all small states during the same period. Either the low level of tax revenues and/or the size of the public wage bill may explain these results. In Comoros, the low level of tax revenue mobilization appears to be the main culprit, with the average public wage bill in percent of GDP over 2013 to 2017 remaining lower than the small states' average (8.7 percent of GDP vs 11.2 percent of GDP).

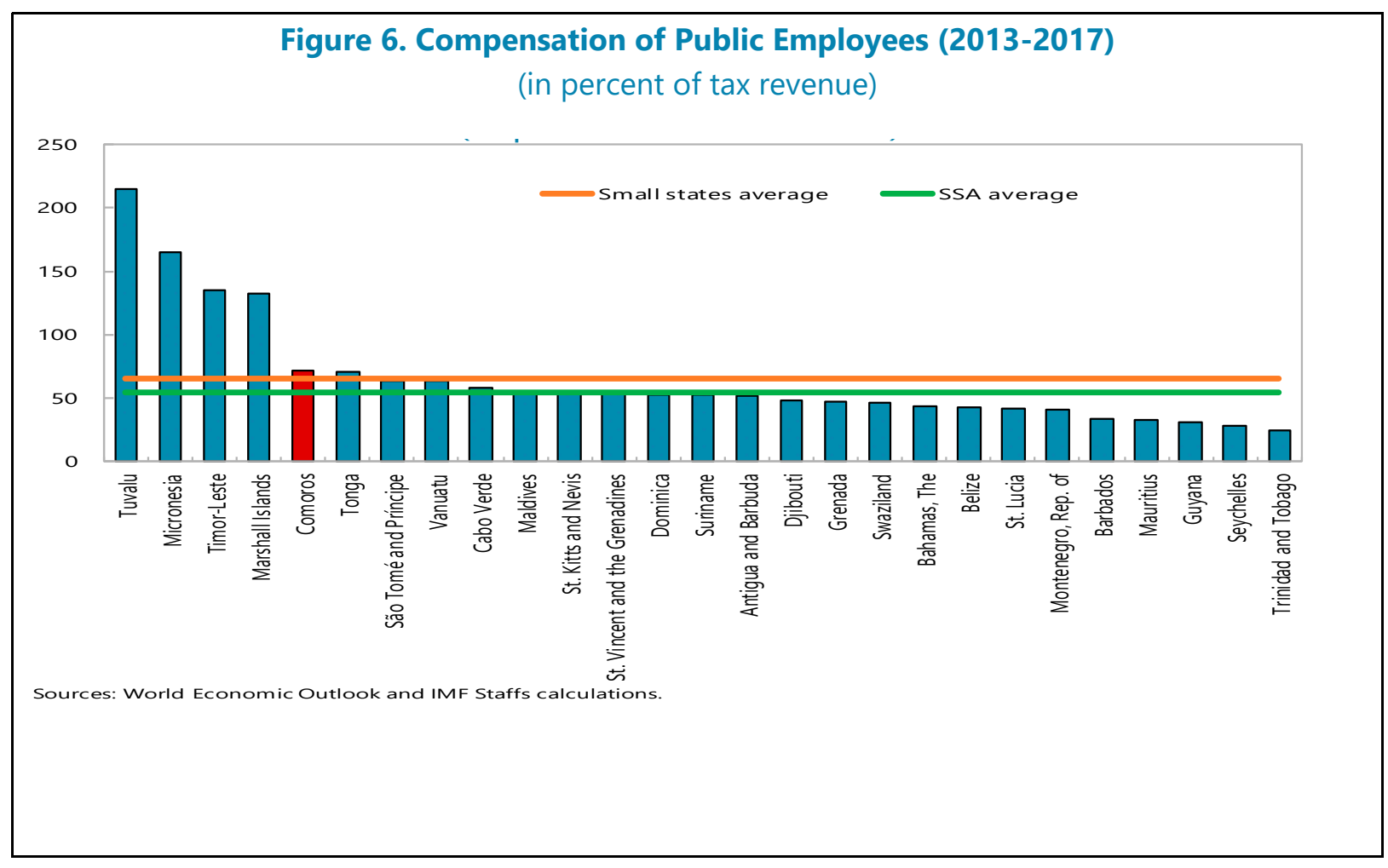

\footnotetext{
${ }^{5}$ Between 2013 and 2017, the standard deviation of external grants received by Comoros was 6.7 percent (the second-highest of all small states), compared with an average 1.8 percent for all small states.
} 


\section{Policy Recommendations for Sustainably Improving Revenue Mobilization in Comoros}

10. Evidence from historical experience in SSA, empirical estimates, as well as comparator country case studies, illustrate how Comoros can sustainably improve revenue mobilization to finance its development strategy. Although individual country context matters, there is potential in many countries in SSA to raise tax revenues by about one percent of GDP per year over the medium term in a sustainable and business-friendly manner (Gaspar and Selassie 2017). Comoros' tax potential, measured as the difference between the tax frontier ${ }^{6}$ and the actual tax ratio, points to a feasible potential increase of about 3 percentage points of GDP in tax revenues, mostly from improvements in transparency and government effectiveness, as well as increasing the productivity of low-yielding direct taxes. Ensuring success in revenue mobilization efforts also requires attention to many factors related to policy design, institutional development, and political support for reform, with economic and political stability also preconditions for reform success (SSA REO 2018). Historical experience also suggests several clear principles for achieving these goals, while deeper analysis of comparator country case studies - Liberia and Georgia - illustrate these principles in action (Akitoby 2018).

11. Several principles for raising tax revenues stand out from historical experience. First, successful reform efforts take time, with successful reform episodes lasting an average of 2 to 7 years. Second, a complete overhaul of fundamental tax administration institutions is often needed. Third, both a clear reform mandate and the sincere engagement of all stakeholders (including civil society and at the highest political levels) are essential. Fourth, tax system simplicity, including reducing both the number of taxes and exemptions, is key, Fifth, reinforcing compliance with existing taxes and introducing new indirect taxes (e.g. Value Added Tax) is important.

12. Liberia's main revenue mobilization reform episode, lasting from 2006 to 2010.After a prolonged internal conflict, Liberia adopted a broad and ambitious reform agenda. This included introducing taxation system building blocks from scratch; voiding or suspending certain tax exemptions which narrowed the tax base; instituting taxes on turnover or import values (e.g. a broad-based goods and services tax and excises, particularly on alcoholic beverages and cigarettes, as well as customs tariffs) underpinned by simple tax legislation; publishing the financial accounts of revenue-generating agencies to address mismanagement of public funds; and computerizing the tax and customs administrations (Akitoby 2017). Over a period of three years, this reform agenda achieved non-resource revenue increases of about 2.6 percentage points each year. This was despite challenges such as low capacity and delays in implementing structural reforms related to eliminating tax exemptions.

\section{Supported by Fund TA, substantial revenue mobilization reforms continued beyond} 2010. These reform efforts focused on strengthening the revenue administration organization;

\footnotetext{
${ }^{6}$ Tax frontier is defined as the maximum theoretical level of tax revenues (measured in percent of GDP) that a country can achieve given certain underlying structural conditions, such as the level of development, the trade openness, the sectoral structure, income distribution, and governance.
} 
defining the organizational structure, administrative and operational frameworks; building a comprehensive risk strategy for large taxpayers, and building the capacity of the Liberia Revenue Authority (LRA), which was established in 2014, to service taxpayers (see IMF 2017 for further details).

14. Despite challenges, Liberia achieved impressive revenue gains through the above reform agenda (Figure 7), although serious macroeconomic shocks affected revenue performance and masked reform impact. During the period $2006-2010$, the above reform agenda achieved non-resource revenue increases of about 2.6 percentage points each year. This was despite challenges such as low capacity and delays in implementing structural reforms related to eliminating tax exemptions. But the impact of some revenue mobilization reforms, particularly in the post-2010 period, was masked by serious macroeconomic shocks. For example, the height of the Ebola crisis coincided with the LRA launch in July 2014, while commodity price (iron ore) shocks have also affected revenue performance in recent years.

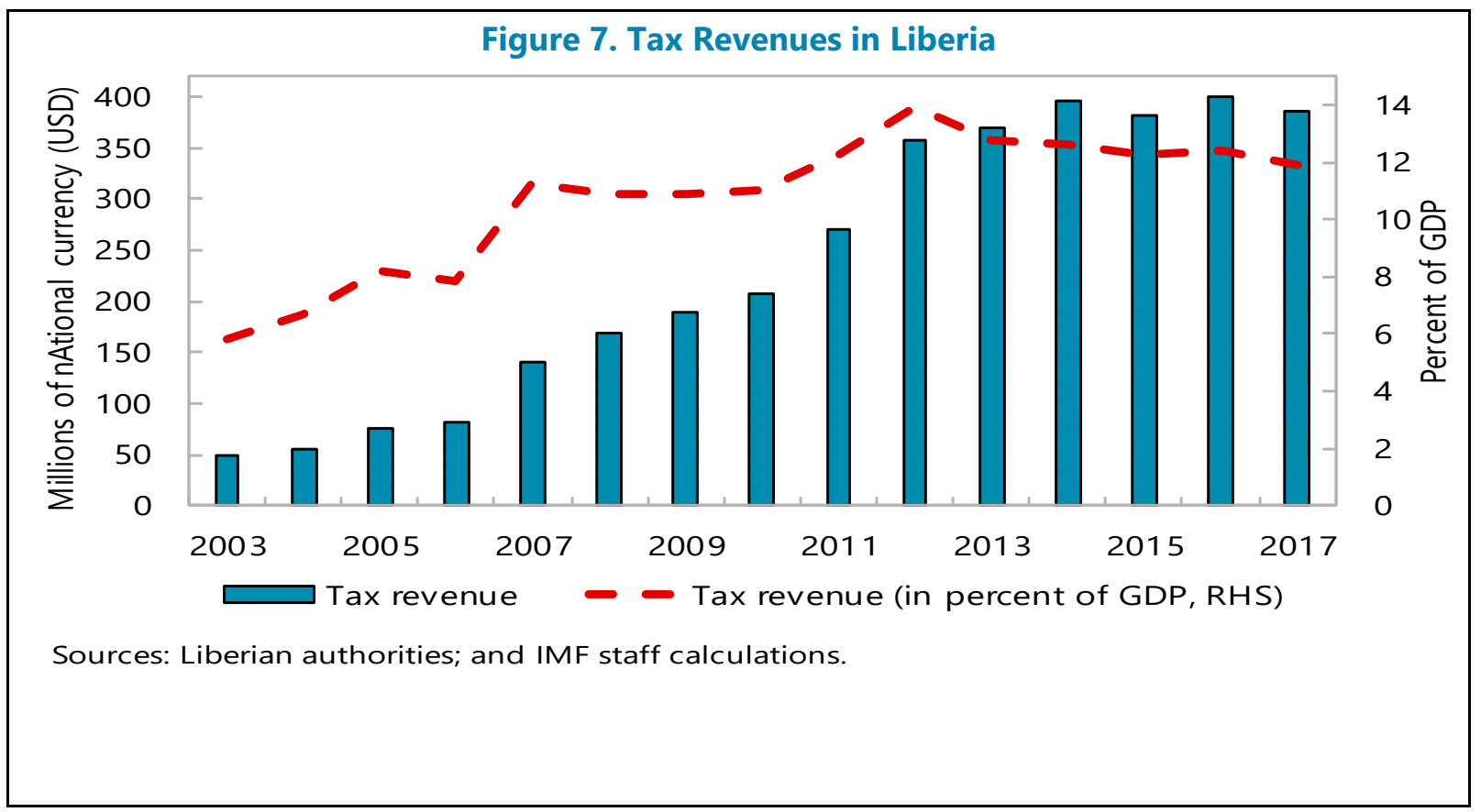

15. Following the $\mathbf{2 0 0 3}$ Rose Revolution, Georgia embarked on a sweeping multiphase tax reform program that curbed tax fraud and evasion, reduced smuggling, and drastically overhauled tax and customs legislations (Figure 8 and Table 2). The reform was multidimensional and included (i) a significant reduction of the formal tax burden (elimination of 16 type of taxes, lowering the rates and simplifying their accounting by streamlining deductions); (ii) restraining ineffective government intervention in private businesses and moving to e-based relations with the taxpayers, including electronic invoicing; (iii) a one-time amnesty on undeclared taxes and tax arrears, with enforcement of fair tax administration practices where voluntary compliance was simplified, while penalties for noncompliance became rather harsh; and (iv) modernizating the Georgian Revenue Service (GRS) structure and establishing it as a legal entity of public law or separate agency, uniting the tax and customs agencies, under the aegis of the Ministry of Finance. This format allowed the GRS to perform state functions and earn revenue from consulting and other services to the taxpayers, the proceeds of which 
were used for employee bonuses. Higher employee salaries served as an incentive for better work and a shield against corruption. The fight against corruption was fully fledged and the financial police was created.

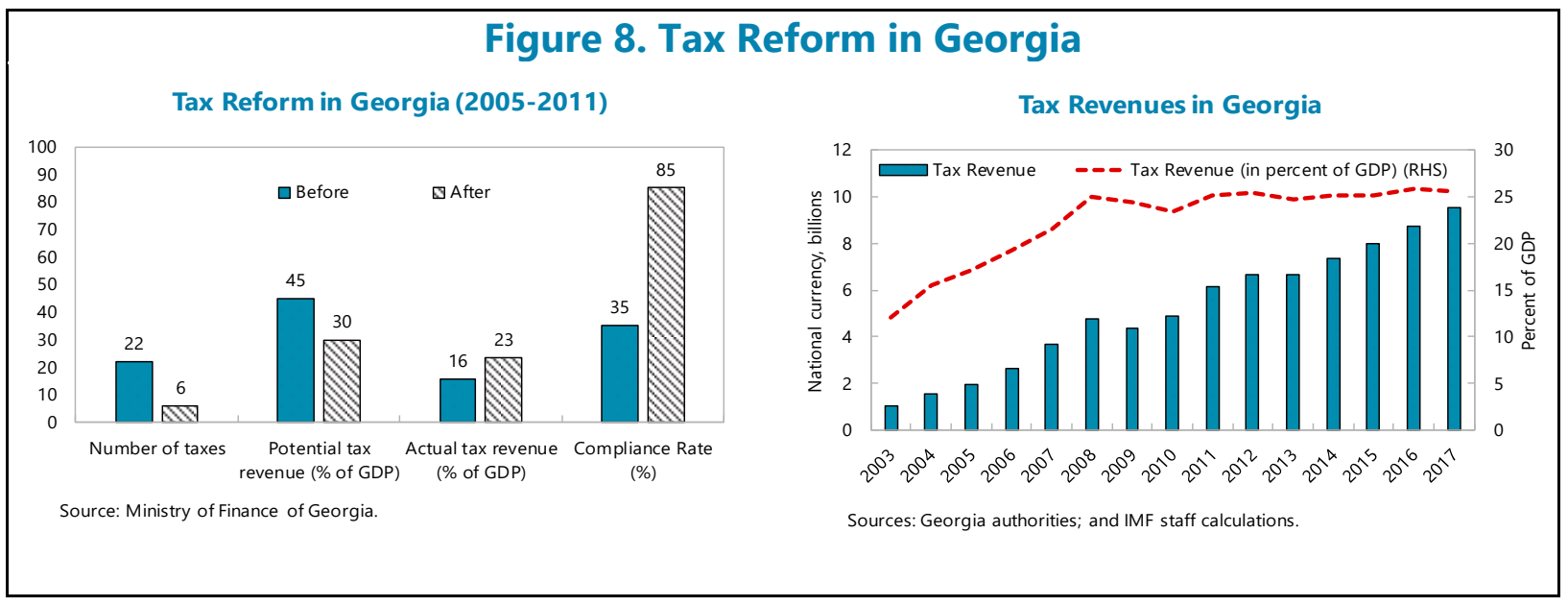

\begin{tabular}{|c|c|c|c|c|c|c|c|c|}
\hline \multicolumn{9}{|c|}{ Table 2. Comoros: Key System Indicators in Georgia } \\
\hline & \multicolumn{2}{|c|}{ First phase } & \multicolumn{3}{|c|}{ Second phase } & \multirow[b]{2}{*}{2009} & \multicolumn{2}{|c|}{ Third phase } \\
\hline & 2004 & 2005 & 2006 & 2007 & 2008 & & 2010 & 2011 \\
\hline Number of taxes & 21 & 7 & 7 & 7 & 6 & 6 & 6 & 6 \\
\hline VAT rate (\%) & 20 & 20 & 18 & 18 & 18 & 18 & 18 & 18 \\
\hline Income tax (\%) & $12-20$ & 12 & 12 & 12 & & & & \\
\hline & & & & & 25 & 20 & 20 & 20 \\
\hline Social securitiy contribution (\%) & 33 & 20 & 20 & 20 & & & & \\
\hline Corporate profit tax (\%) & 20 & 20 & 20 & 20 & 15 & 15 & 15 & 15 \\
\hline Dividend \& interest income tax (\%) & 10 & 10 & 10 & 10 & 10 & 5 & 5 & 5 \\
\hline Source: Georgian Ministry of Finance. & & & & & & & & \\
\hline
\end{tabular}

\section{The second reform wave focused on improving institutional capacity, scaling up} investment, and introducing comprehensive IT solutions for tax and customs administration. Measures included a unified taxpayer database and e-services, such as individual taxpayer electronic pages, where the taxpayers can monitor online their tax payments, status and taxes due and interact with the GRS from their offices. The tax system was further simplified and tax rates were lowered. For example, sine 2008 personal income tax rates were combined with the social contribution into a single tax rate of 20 percent. $^{7}$ Taxes on corporate dividends and interest earnings were reduced from 10 to 5 percent in 2009 (Table 2). The final phase involved harmonizing the tax law with international best practices. Different taxation regimes were also introduced to accommodate different taxpayers'

\footnotetext{
${ }^{7}$ The social tax was merged with the income tax as the pension fund was merged with the budget at the same time. The social tax provided funding for the pension fund.
} 
needs, particularly SMEs. In addition, the GRS further improved tax collection by streamlining and automating most processes, introducing risk-based audit management and vastly expanding eservices. As result, tax compliance costs significantly decreased and tax efficiency further improved (World Bank 2012).

17. Better tax administration and simplified business regulations resulted in a rapid and sustainable growth of tax revenues in Georgia. Taxpayer registration more than doubled from 2005 to 2008 (OECD 2015), with tax form simplification and the rapid build-up of the e-filing system resulting in a drastic increase in tax compliance. This was reflected in a more-than-doubling of the tax revenue to GDP ratio, to 25.2 percent of GDP as at end of 2011 (Figure 8).

18. Tax reforms in Georgia largely succeeded because of successful complementary efforts to reinstate good governance through stamping out public corruption, which also benefitted perceptions of the business environment. The government's political will, determination and quick action were critical to the success of the reforms. Perceptions of Georgia's business environment significantly improved as a result of the government's multipronged approach, with Foreign Direct Investment (FDI) increasing significantly between 2003 and 2008 (Figure 9). Also reflecting this, Figure 9. Foreign Direct Investment (FDI) in Georgia)

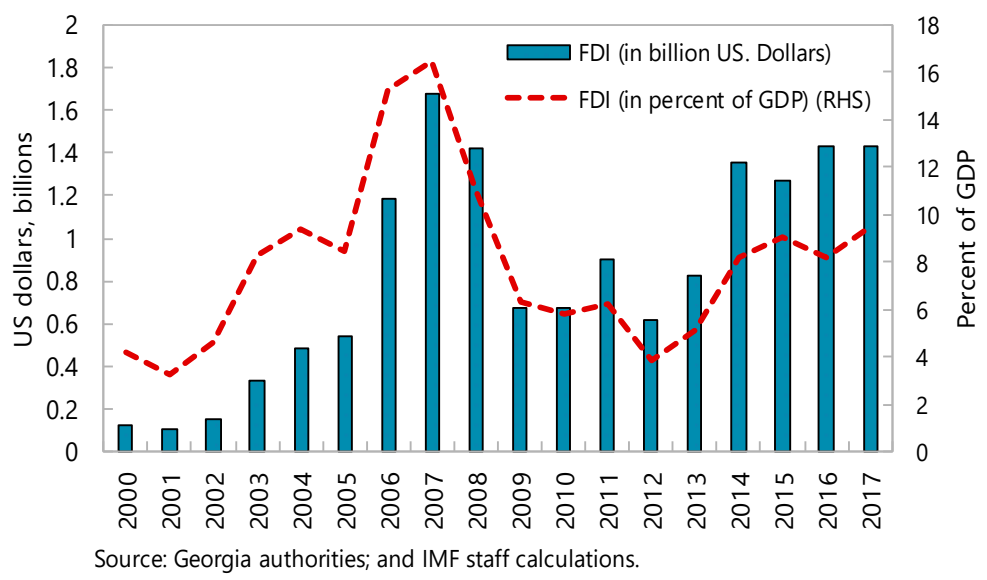

Georgia achieved dramatic improvements in their Doing Business ranking, moving from $111^{\text {th }}$ place in 2005 to $12^{\text {th }}$ place in 2011 (and $9^{\text {th }}$ place in 2018). However, the blunt action that accompanied the sweeping reform program left many sidelined and ultimately resulted in the growing antigovernment tension that ended the reform era in 2012.

\section{Conclusion}

19. Weak revenue mobilization and the reliance on volatile one-off windfall gains remains a significant development challenge for Comoros. Weak revenue mobilization not only makes it more difficult for Comoros to finance its significant development needs, but increases the budget's reliance on uncertain and volatile one-off revenue streams. In turn, these tendencies, combined with unrealistic budgetary goals, hamper budgetary execution and adversely affect budget execution.

20. Sustainably improving revenue mobilization based on realistic and attainable budgetary targets, is key for financing Comoros' medium to long term development goals 
without endangering debt sustainability. Broadening the tax base and thereby increasing the tax ratio to develop more predictable budgetary financing sources will aid execution of Comoros' ambitious investment program that underpins the country's development strategy. At the same time, this will help improve investment expenditure execution and limit the recourse to potentially unsustainable external borrowing.

21. Current reform efforts to sustainably increase revenues are heading in the right direction, but significant increases in Comoros' tax ratio remain realistically feasible through further following the example of comparator country experience for effective reform implementation. In 2017, the increased effort on tax and customs led to the highest annual tax revenue increase in the last fifteen years (2.6 percentage points of GDP), with the tax ratio reaching 15.5 percent of GDP. Deepening these efforts, by further improvement in both Customs and tax administration and adopting a medium-term revenue strategy to strengthen the basic building blocks of effective tax administration and broaden the tax base could lead to a sizeable increase of tax revenues. Such reforms could focus on recovering the stock of tax arrears; recovering unpaid corporate taxes; intensifying the tax audit program; following up on income tax non-declaration, and maintaining the reversal of costly tax expenditures, such as Customs exemptions. Enlarging the tax base could be achieved by facilitating the formalization process for informal production units through enhancing the quality of tax administration services; reducing the cost of formality and compliance by adopting an adequate and friendly legislative framework with micro-and-small enterprises; and introducing indirect taxes to reduce the proportion of direct taxes in the overall tax take. At the same time, the productivity of existing direct taxes (personal income taxes and corporate income taxes) - which by regional standards are not very efficient in Comoros-could be increased to yield significant increases in the tax ratio. 


\section{References}

Akitoby, B. (2018). Raising Revenue Five Country Cases Illustrate how Best to Improve Tax Collection, Finance \& Development, March 2018, Vol. 55, No. 1.

Gaspar, V., \& Selassie, A. A. (2017). Taxes, Debt and Development: A One-Percent Rule to Raise Revenues in Africa. IMF blog. Advance online version available at https://blogs.imf.org/2017/12/05/taxes-debt-and-development-a-one-percent-rule-to-raiserevenues-in-africa.

IMF (2017), 'Multi-Country Report: Building Fiscal Capacity in Fragile States - Case Studies', IMF Country Report 17/153, Washington DC, June.

OECD (2015). "Examples of Successful DRM Reforms and the Role of International Co-operation," Discussion Paper, Eschborn, Germany.

Sub-Saharan Africa Regional Economic Outlook (2018). Domestic Revenue Mobilization and Private Investment, World Economic and Financial Surveys, International Monetary Fund, Washington DC, April.

World Bank. (2012). Fighting Corruption in Public Services: Chronicling Georgia's Reforms, Washington DC, United States. 


\section{INFORMALITY AND GENDER INEQUALITY IN COMOROS $^{1}$}

The informal economy is a key feature of most sub-Saharan African (SSA) economies, contributing between 25 and 65 percent of GDP with most economies likely to have large informal sectors for many years to come (SSA Regional Economic Outlook, May 2017). This chapter investigates the links between the informal sector and gender inequality in Comoros, and compares with experience in other SSA countries. Findings suggest that informal employment constitutes the bulk of female employment in SSA and Comoros and that reducing gender inequality is a key step toward development. In addition, the analysis of informal production units in Comoros suggests that informality is associated with lack of awareness of tax and social security procedures and the burden of complex and costly tax rules. These results present both opportunities and challenges for policymakers: increasing incentives for informal units to formalize could enhance gender equality and income equality. Empowering and improving women's activities could reduce gender inequality and boost growth.

\section{A. Introduction}

1. Informal employment is a broad concept that has evolved over time. As a result, its comparability over time and between countries is subject to accounting for country specifics, differences in employment regulation, and the continuous changes in the definition of informal sector in response to international standards. ${ }^{2}$ In general, informal employment includes all persons whose employment does not comply with national labor legislation, is not subject to income taxation, and is not eligible for social protection or the right to certain benefits such as dismissal indemnity, and sick leave or paid leave amongst others. In this regard, concept of informal employment is defined by the employment conditions for employees both in their main and secondary activities.

\section{The challenge is to create an economic environment in which the formal sector can} thrive while creating opportunities for the informal sector to maintain or improve living standards. The informal sector provides employment, which is particularly important in countries where the demographics are such that there is a large and growing working-age population that outstrips the pace of job creation in the formal sector. However, the informal employment tends to be concentrated among women and in low productivity activities. Increasing the share of the formal sector through the movement of informal sector entities into the formal sector would increase productivity in the economy, and provide resources (through an expansion of the tax base and revenue mobilization) to finance public investment and promote sustained and inclusive growth.

\footnotetext{
${ }^{1}$ Prepared by Mokhtar Benlamine and Mounir Bari. This chapter has benefited from comments from several IMF colleagues.

${ }^{2}$ The XVII International Conference of Labor Statisticians (ICLS) established the distinction between (i) employment in the informal economy; (ii) informal employment; (iii) employment in the informal sector; and (iv) informal employment outside the informal sector (ILO (2004)).
} 
3. A growing economic literature has associated inequality with lower economic growth. While the female labor participation ratio in SSA is among the highest in the world, Comoros' female labor participation ratio remains one of the lowest in the region. Nevertheless, female workers play a vital role in the informal economy in Comoros, and empowering female workers could be a key step toward their transition to the formal economy.

4. For Comoros, a better understanding of the informal sector is also important to tackle structural fiscal imbalances. To this end, policies aimed at addressing gender inequality in the labor market and improving female access to formal employment could help boost economic growth and unleash the potential of the informal production units (IPUs). The ratio of tax revenues to GDP in Comoros is one of the lowest among Small States (defined as countries with population under 1.5 million) and reflects an important concentration on customs and a set of public companies (see Selected Issues chapter on Weak Domestic Revenue and Volatile Windfall Revenues).

5. Against this background, this chapter highlights key features of informality, the significance of gender inequality in formal employment, and the key drivers of informality in Comoros and compares with SSA experience. The rest of the chatper is divided into four sections. Section B describes stylized facts about informal employment in total and nonagricultural employment for Comoros and a set of SSA countries. Section C investigates the relationship between gender, informal employment and income inequality. Section $D$ discusses the role of informal production units in Comoros, their key features and their role in public finances. The last section concludes with some policy recommendations.

\section{B. Informal Employment in Comoros and SSA}

\section{Female participation in total labor force is low in Comoros compared to SSA (Figure 1).}

Comoros' female participation in the labor force increased from 37.2 percent in 1990 to 41.5 percent in 2017. Even though this increase is among the highest in SSA, it remains low compared to the SSA experience. Considering these results, we focus on the quality of employment by analyzing the access to formal and informal employment.
Figure 1. Labor Force, Female

(\% of total labor force)

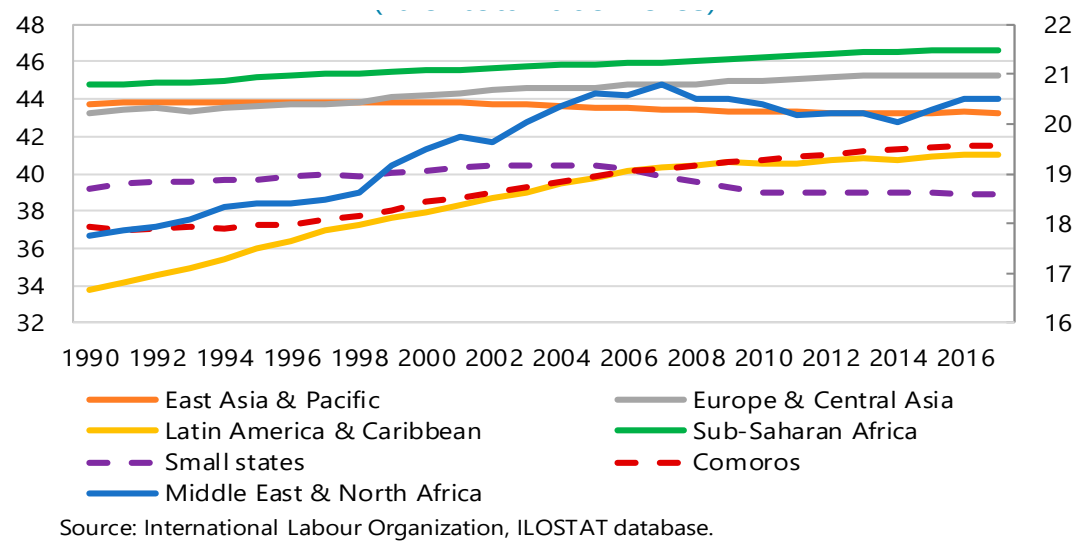


7. Data collected from a sample of 21 SSA countries indicates that informal employment constitutes the lion's share of total employment and particularly in Comoros (Figure 2). Using a constructed database based on ILO data and the most recent available data from national surveys on informal sector and/or employment in individual countries, we find that, on average, informal employment constitutes 82.4 percent of total employment. This share varies across countries from a minimum of 30 percent in South

Figure 2. Share of informal Employment in Total employment

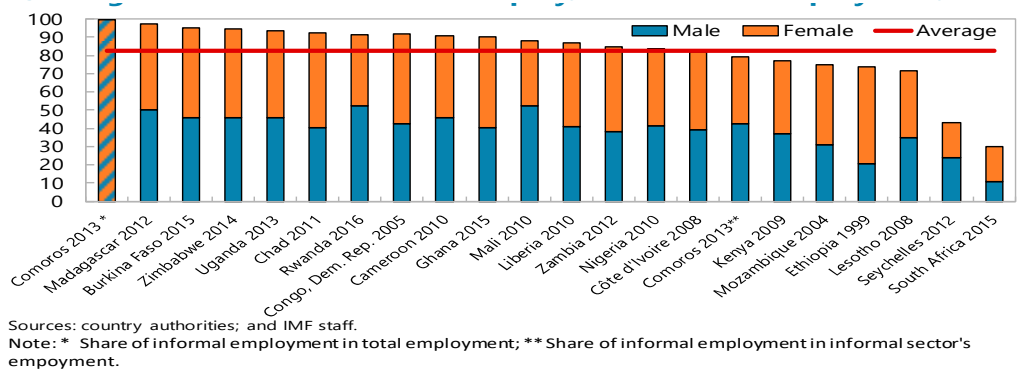

Africa (2015) to a maximum of 99.5 percent in Comoros (2013). In Comoros and likely in some other countries, civil servants do not comply with social protection requirement and as a result are registered as informal employees. The sample median hovers around 88 percent reflecting the importance of informality in creating jobs.

8. Informal employment is more concentrated among females in Comoros and SSA. While a first lecture of the previous chart of informal employment distribution among the population of male and female reveals some parity, a closer look suggests that the share of informal employment to total employment among females is much higher than for males. In fact, the sample average for female employment in formal sector represents 86.5 percent, much higher than respective share for male (76.8 percent). Excluding both Seychelles and South Africa, theses shares reach 91.3 percent for female and 81.4 percent for male. Given that data on informal employment by gender is not available for total employment in Comoros, the analyses are conducted using the available structure of informal employment by gender in the informal sector. ${ }^{3}$ This implies that gender disparity is greater in Comoros with a concentration of 97.2 percent among females with informal employment (the highest after Madagascar) and 68.2 percent for male.

\section{Informal} employment in the nonagriculture sector is relatively lower in Comoros and SSA. On average, informal employment constitutes 67.5 percent of non-agricultural employment

Figure 3. Share of Informal employment in Non-Agriculture (in percent)

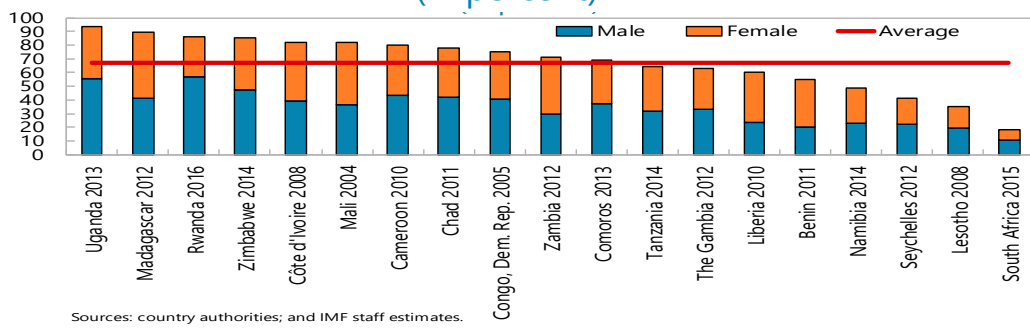

\footnotetext{
${ }^{3}$ In addition, IPUs represent all the units of production of goods and/or services held by an employer or a selfemployed worker operating in Comoros and who does not possess a tax identification number and/or maintain accounting records. IPUs could provide both formal and informal employment.
} 
in 19 SSA countries (Figure 3). This average varies from 17.8 percent (South Africa 2015) to 93.2 percent (Uganda 2013). With a proportion of 69 percent, Comoros level of informal employment in the non-agriculture sector remains higher than the sample average.

10. In non-agriculture, the informal employment is more concentrated among females. The share of informal employment in non-agricultural employment among female constitutes on average 77.9 percent, compared to 66.8 percent for male. Excluding Seychelles (2012), Lesotho (2008) and South Africa (2015) where these shares averaged 29.9 percent for females and 32.9 percent for males, the share of informal employment in non-agricultural employment

Figure 4. Male to Female Ratio and Informal Employment

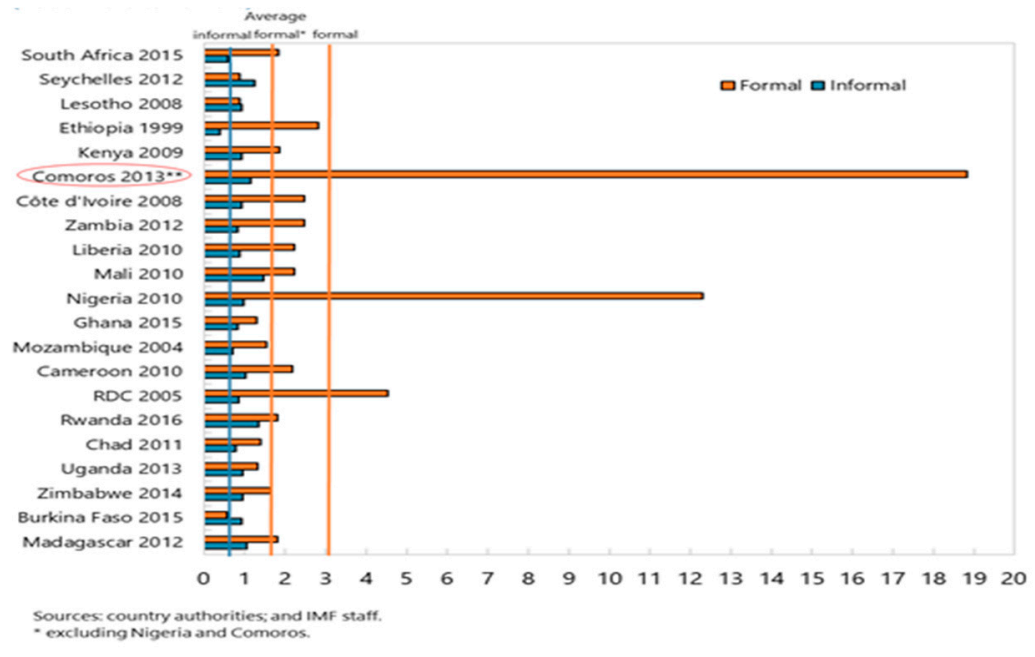
constitutes 80.3 percent of females and 68.2 percent of males. In Comoros, 78.8 percent of female (62.4 percent of males) working in the non-agriculture are informal. Non-agricultural employment seems to be driven by informal employment with a higher concentration among females. In addition, for each woman with formal employment, there are two men with formal employment.

11. Informal employment is more gender equal than formal employment (Figures 4 and 5). Informal employment represents the bulk of total employment in SSA and the main driver of employment among women. Constituting on average 20.4 percent of male employment and only 11.4 percent of female employment, formal employment is more important among males. For each female with formal employment, there are 3.2 males with formal employment, with a maximum of 18 in the Comoros.
Figure 5. Male to Female Ratio in formal and Informal Employment in Non- Agriculture

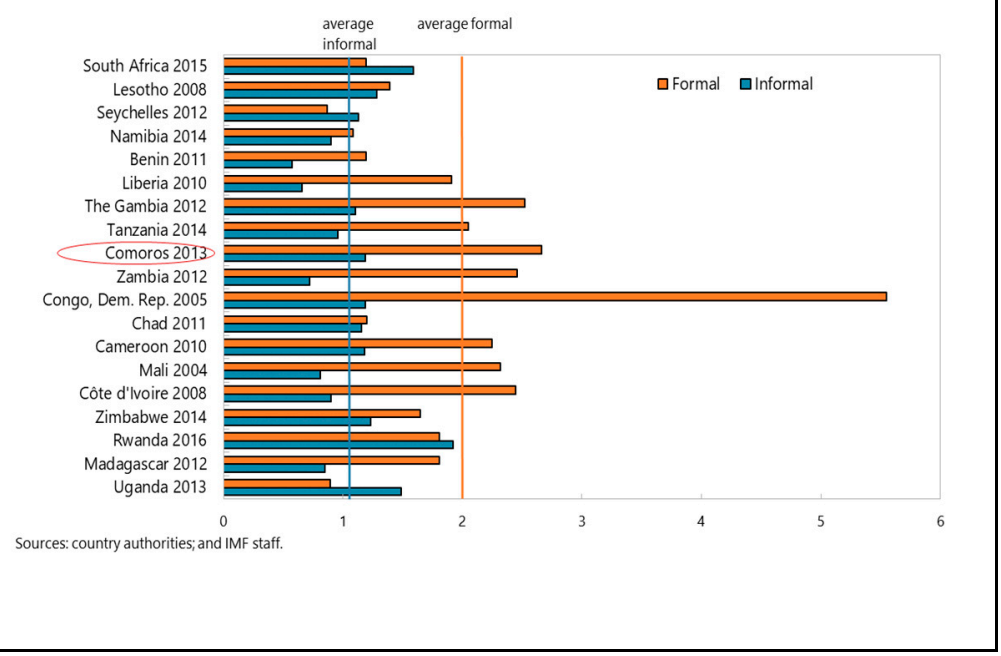


Conversely, for each female with informal employment, there are 0.9 male with informal employment. This suggests that gender parity is more important in informal employment than in formal employment, given that females in SSA are more likely to find informal employment than formal employment. Excluding agriculture, these results remain unchanged, with a ratio of 2 males with formal employment for each female with formal employment and 1.1 male for each female with informal employment.

\section{Gender, Informal Employment and Income Inequality: Preliminary Findings}

\section{Female participation in the Comorian labor force is the lowest among SSA countries}

(Figure 6). Female labor participation in Comoros is the lowest in Sub-Saharan Africa. Between 1990 and 2017, female labor participation averaged 33.2 percent in Comoros, compared with 62.4 percent on average for SSA countries. In addition, the annual increase of this indicator over the period 19902017 in Comoros was 0.16 percentage point (pp) per year, much lower compared with other countries with same levels of female participation in the labor force at the beginning of the nineties, including Senegal $(0.43$ pp), Mali (0.91 pp), Gabon (0.23 $\mathrm{pp})$, Swaziland (0.18 pp) and Mauritius (0.24 pp).

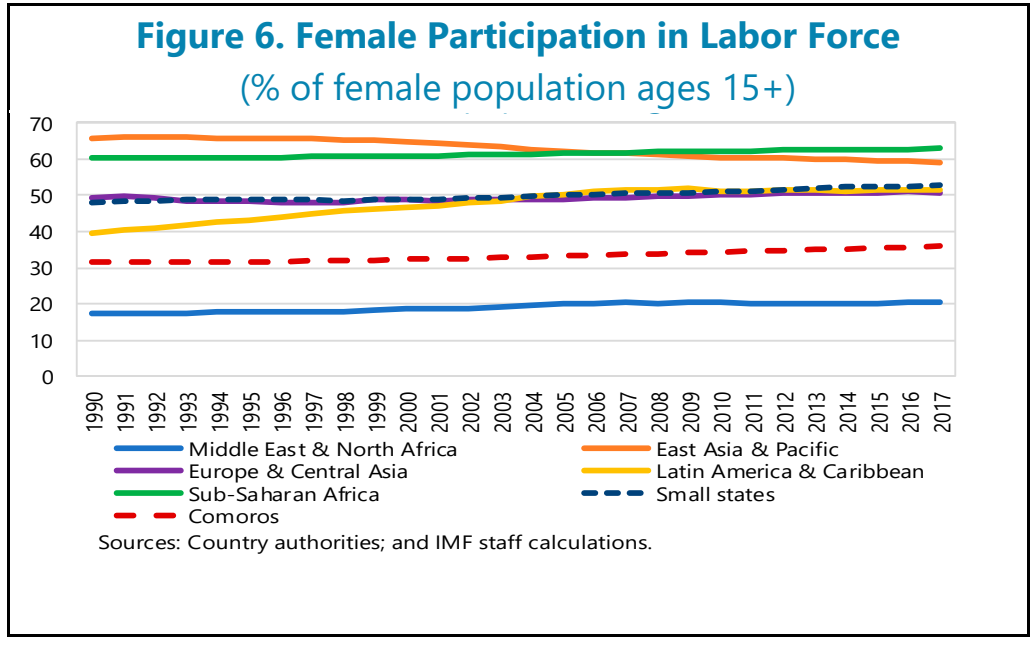

13. Gender inequality remains widespread in SSA. The gender inequality index shows a declining trend and lower level of gender inequality in Sub-Saharan Africa in comparison with other regions, such as the Middle East and North Africa, and Latin America and the Caribbean. In Comoros, 50.6 percent of the working-age population is female, while only 29.6 percent of female workers are employed compared with 53.2 percent of males. Also, according to the Comorian statistical agency INSEED survey, 67.1 percent of female employees have precarious jobs compared with 47.3 percent of males. These results highlight the sizeable gender gap in employment access and quality in Comoros. Regarding education, the gender parity index (GPI) has increased in Comoros from 0.46 to 0.98 during the period 1971-2014. ${ }^{4}$ For SSA countries, this index improved from 0.71 to 0.92 during the same period, highlighting the remarkable progress reached by Comoros. In addition, maternal mortality ratio remains lower in Comoros (335 per 100.000 live births) in comparison with SSA countries (547 per 100.000 live births) in 2015 . However, inequality is more pronounced in Comoros with respect to bank account ownership, with 26 percent of men owning an account and only 18

\footnotetext{
${ }^{4}$ The GPI stands for the gender parity index for gross enrollment ratio in primary and secondary education. It reflects the ratio of girls to boys enrolled at primary and secondary levels in public and private schools.
} 
percent for women in 2011. This represents one of the largest gaps in SSA countries.

14. Reducing gender inequality can reduce income inequality and boost growth. ${ }^{5}$ During the period 1995-2015, simple correlations calculations indicated a positive correlation of 58.6 percent between gender inequality and income inequality (Figure 7). ${ }^{6}$ These results are in line with the findings of Gonzales et al. (2015), indicating that gender inequality in general is an important source of income inequality. Moreover, an analysis of the relationship between growth and inequality and redistribution by Ostry et al. (2014) indicates that low levels of net income inequality have been closely associated with faster growth

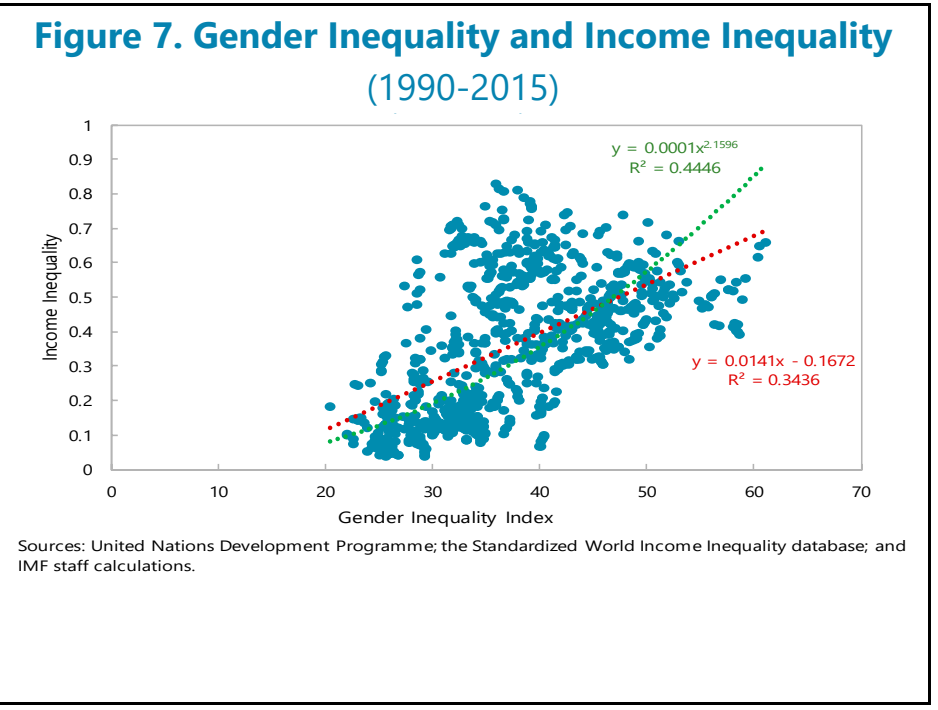
and longer periods of strong growth for a large number of advanced and developing countries.

\section{Gender inequality impacts growth through channels other than income inequality.}

Reducing gender inequality can boost economic growth. Hakura et al. (2016) finds a negative effect of gender inequality on growth, estimating that annual GDP per capita growth in Sub-Saharan Africa could be 0.9 percentage points higher, on average, if income and gender inequality were reduced to the levels observed in the fast-growing Association of South East Asian Nations (ASEAN). In addition, they find that gender inequality impacts growth through channels other than income inequality. For fragile states, the authors estimate that reducing gender inequality could boost annual per capita GDP growth by two-thirds percentage points.

\section{The Role of Informal Production Units in Comoros}

\section{Characteristics and features}

16. Informal production units are the main driver of employment in Comoros (Figure 8). Informal production units (IPUs) represent all the units of production of goods and/or services held by an employer or a selfemployed worker operating in Comoros
Figure 8. Employment in Comoros, 2013

(number of people)

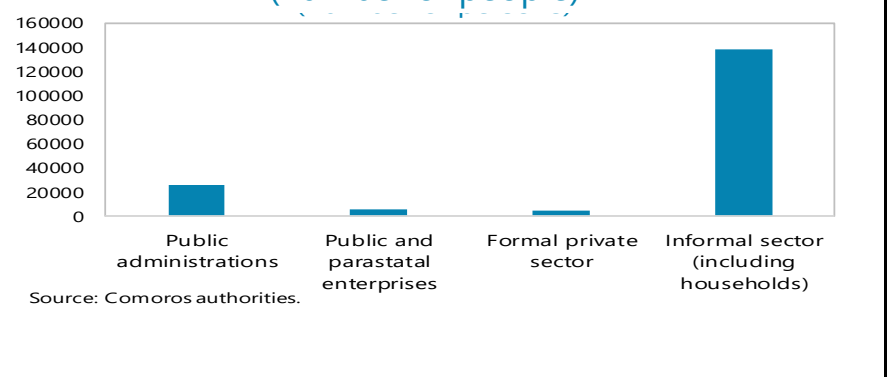

\footnotetext{
${ }^{5}$ Gender inequality is examined using the United Nations gender inequality index, which measures gender inequality in three key aspects of human development: reproductive health, empowerment and economic status.

${ }^{6}$ Gender inequality is measured by the Standardized World Income Inequality Database (SWIID) using the estimate of Gini index of inequality in equivalized (square root scale) household disposable (post-tax, post-transfer) income.
} 
and who does not possess a tax identification number and/or maintain accounting records.

According to a survey conducted by the Comorian statistical agency INSEED with the assistance of AFRISTAT, the IPUs contribute 79.2 percent to employment in Comoros and 97.4 percent of workers in formal production units have informal employment.

17. The creation of informal production units is primarily led by women (Figure 9). During the period 1990-2013, the total number of informal production units increased from 9.557 to 64.975 units. More specifically, and between 2009 and 2013, 40.8 percent of the IPUs were created, while 51 percent of those were concentrated in the trade sector. On average, women headed 47.6 percent of the informal units created during the period 1990- 2013. During the same period, the share of informal units created by females were even larger, with an average of 62.7 percent.

18. The geographical distribution of IPUs reflects the importance of these units in the three islands of Comoros. The geographical distribution of the IPU's was as follows: 49.8 percent of those units are in Ngazidja, including 12.5 percent in the capital Moroni, 47.3 percent in Ndzouani, and 2.4 percent in Mwali. At the beginning of their activities, 83.3 percent of the IPU promoters in Comoros created their own unit and 68 percent of the IPUs had only one person as labor (22.7 percent had 2 employees). The age of the production

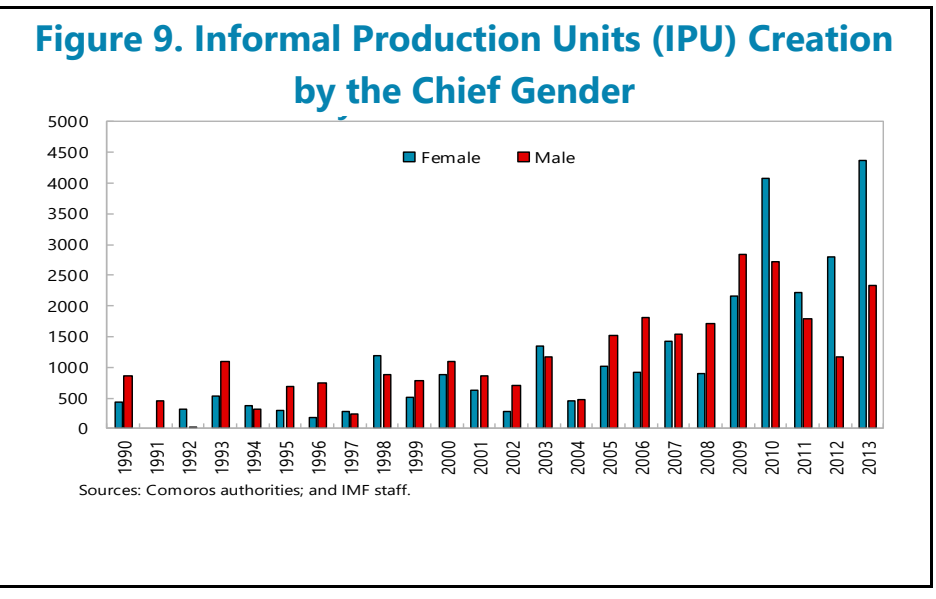
units ranges from one year - as it is widely the case in the hotel and restaurants sector as well as the energy sector - to 36 years in the forestry sector in Ndzouani. The average age of informal production units is 11 years.

19. IPUs are concentrated in the agriculture and trade sectors (Figure 10). IPUs operating in the primary sector constitute 38.7 percent of the total, while 33.1 percent operate in trade and 20.1 percent in industrial activities. The agriculture and trade sectors represent the lion's share

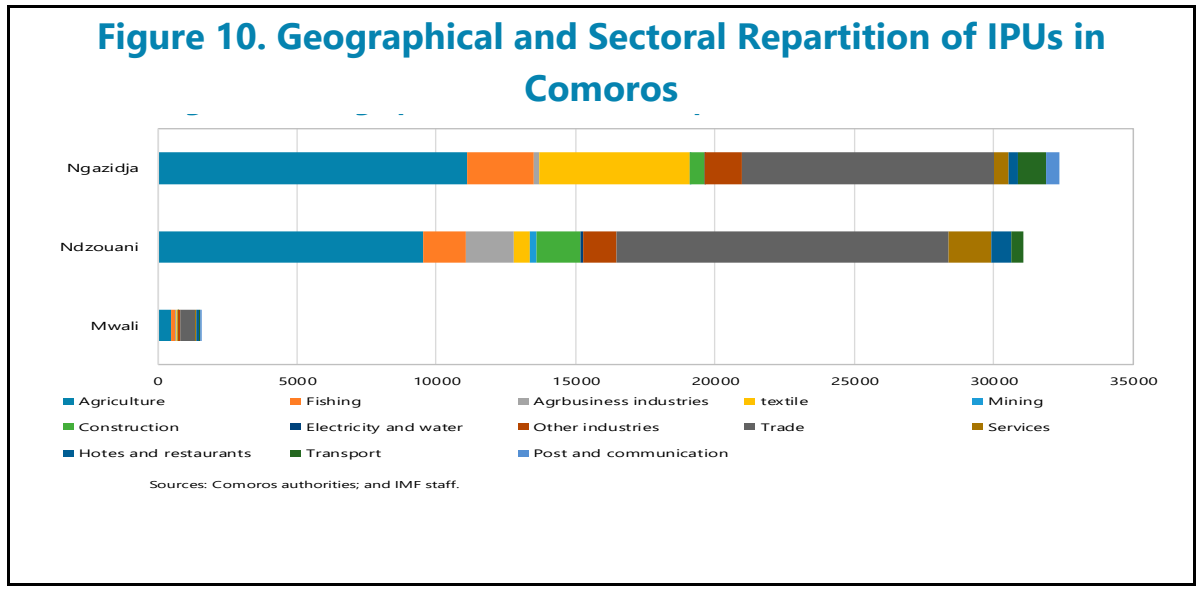
of IPUs employment in the three islands, with an average of 37.5 and 15.7 percent, respectively. 


\section{IPUs and Public Administrations in Comoros}

20. Most of IPUs operate outside the tax system (Table 1). In 2013, only 5.7 percent of the IPUs complied with trade registration requirements. Regarding the tax ID registration requirement, only 1.2 percent of the IPUs complied in 2013, with a maximal of 4.2 percent in wholesale trade.

\section{Regulatory compliance}

\begin{tabular}{||lcc|}
\hline \multicolumn{1}{|c|}{$\begin{array}{c}\text { Table 1. Comoros: Compliance with Regulations (in } \\
\text { percent) }\end{array}$} \\
\hline \multicolumn{3}{|c|}{ Trage registration } \\
\hline Comoros & 5.7 & Tax ID \\
\hline Moroni & 9.0 & 1.2 \\
\hline Ngazidja (exc. Moroni) & 1.2 & 5.7 \\
\hline Ndzouani & 7.8 & 0.1 \\
\hline Mwali & 16.9 & 0.8 \\
\hline Source: National authorities. & & 4.3 \\
\hline & & \\
\hline
\end{tabular}
appears not to be correlated with IPU's subsector age, the availability of workplace or the combination of the two. Available data on the age of the IPUs by subsectors and their compliance rate indicates that there is no correlation between the two. For example, the forestry sector composed of 329 units located exclusively in Ndzouani, are the oldest among all the units, with an average age of 36 years. However, no unit complied with the trade registration and the tax ID requirements. In general, 14 percent of the units are in subsectors with no compliance at all with the trade registry requirement while their average age is 14.2 years. For the tax identification number, 50 percent of these units are in subsectors without tax IDs with an average age of 14.7 years.

22. The lack of regulatory awareness, high costs related to formality, and a complex tax system are key drivers of informality associated with IPUs in Comoros (Figure 11). Using the INSEED survey, we examine the reason of noncompliance with the three rules, namely, trade registration, tax ID and social security requirement. Results suggest that IPUs do not use public services in Comoros: 76.4 percent of the informal units claim not to use basic public services, and more than 80 percent of respondents cited the lack of awareness and the burden of complex and costly tax procedures as the main reasons behind informality and noncompliance. For trade registration, 57.7 percent of the respondents indicate that they were either not aware of the obligation to register for the trade activity or that it was not necessary to comply with it. ${ }^{7}$ In addition, 26 percent of respondents indicated that the

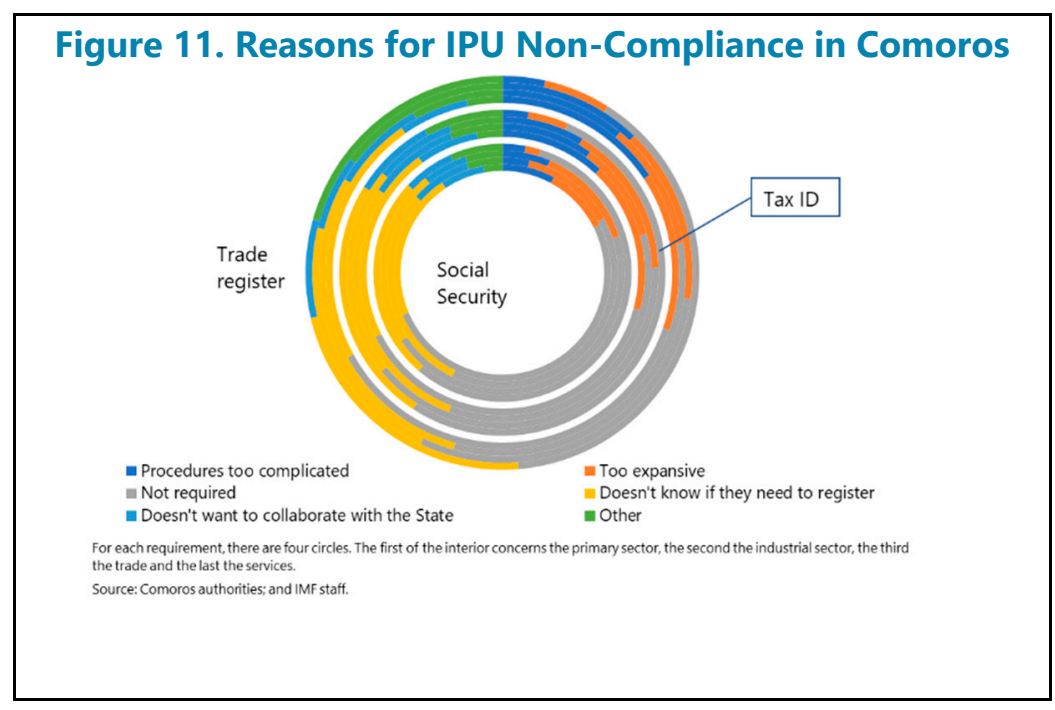

\footnotetext{
${ }^{7}$ In Comoros, it is mandatory for a production unit to acquire a Tax Identification Number (TIN).
} 
cost and complexity of the procedures was another reason for noncompliance. For tax ID, the results suggest that lack of awareness explains 62.8 percent of noncompliance in Comoros, and 24.1 percent of the respondents mentioned the significant cost and the complexity of procedures. Similar results are observed when compliance with the social security requirement is examined.

\section{E. Conclusions and Policy Recommendations}

23. Informal employment is the bulk of employment in SSA countries. One of the main challenges in SSA countries is not only to create formal jobs, but also to increase the productivity of most of the workforce operating in the informal sector and to facilitate the process toward formality. The legalist school of thoughts led by De Soto (1989 and 2000) consider the informal sector as a group of brave micro-entrepreneurs choosing informality to avoid cumbersome procedures. This theory states that the regulations imposed by governments exclude and block a large fraction of entrepreneurs to move to formality.

24. Reducing gender inequality is a key step toward development (Figure 12). This study highlights the importance of informal employment within females. It brings also evidence that's the informal employment is more gender equal than formal employment. In this sense, facilitating the process of formalization could increase gender equality in formal employment, through increasing the access to formal jobs. Considering the positive correlation between gender inequality and income inequality, this could also lead to an increase of income equality. The growing literature on the effects of both gender inequality and income inequality on growth, advocates for a sizeable and durable increase of economic growth when inequality is addressed. While Comoros is struggling in a low path of growth, with a negative evolution of GDP per capita on average over the last ten years, tackling gender inequality could boost economic development in the country. Since 1990, Comoros has the lowest female participation in the labor force compared with Sub-Saharan African countries. This constitutes a major impediment to the development of the country.

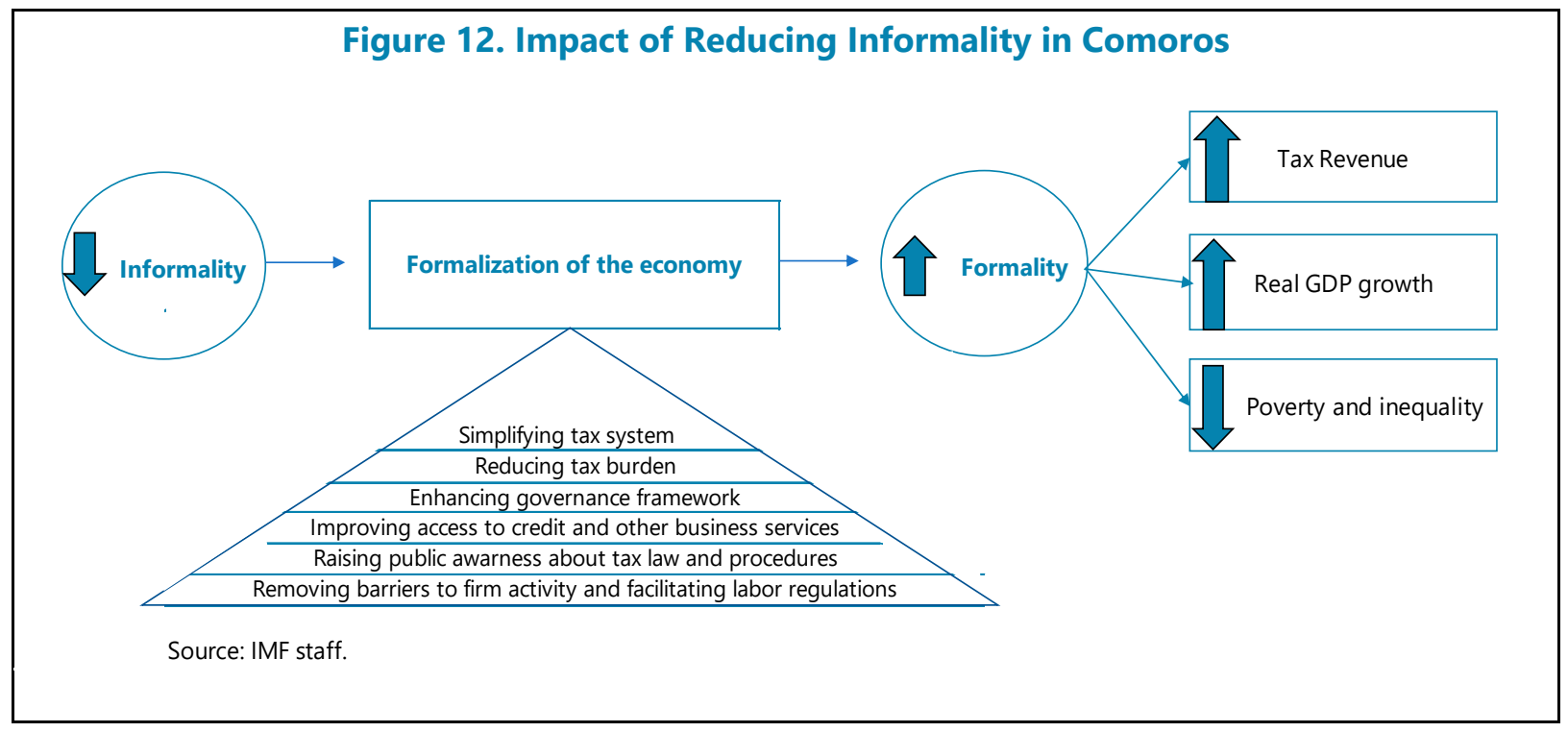




\section{The lack of procedures awareness and the burden of complex and costly tax} procedures are the key factors driving informality in Comoros. Considering the importance of informal employment and the informal sector in Comoros and SSA countries, these results advocate for the importance of increasing tax obligation awareness. In this sense, enhancing the quality of the tax administration services in parallel with reducing the cost of formality and compliance by adopting an adequate and friendly legislative framework with micro-and-small enterprises could support the process of formalization. Streamlining labor regulations is also a key element in the expansion of the formal sector. Finally, alleviating financial constraints by increasing the access and reducing the cost of financial services could improve the efficiency of the informal sector and bring more incentives to formalize. Experience from fragile and conflict-affected economies has shown that adopting modern technologies such as mobile banking can play an important role in promoting financial inclusion and reducing the cost of financial access (Findex 2017). 


\section{References}

Chong, A., \& Gradstein, M. (2007). Inequality and Informality Journal of Public Economics 91 (2007) 159-179.

Demirgüç-Kunt, A., Klapper, L., Singer, D., Ansar, A., \& Hess, J. (2017). The global Findex Database 2017: Measuring financial inclusion and the fintech revolution. World Bank Group.

Gonzales, C., Jain-Chandra, S., Kochhar, K., Newiak, M., \& Zeinullayev, T. (2015). Catalyst for Change: Empowering Women and Tackling Income Inequality. IMF Staff Discussion note 15/20.

Ostry, J. D., Berg, A., \& Tsangarides, C. G. (2014). Redistribution, Inequality, and Growth. IMF Staff Discussion note $14 / 02$.

Solt, F., (2016). The Standardized World Income Inequality Database. Social Science Quarterly 97. SWIID Version 6.2, March 2018.

Hakura, D. S., Hussain, M., Newiak, M., Thakoor, V., \& Yang, F. (2016). Inequality, Gender Gaps and Economic Growth: Comparative Evidence for Sub-Saharan Africa. IMF working paper 16/111.

ILO (2004). Final Report of the 17th International Labor Statisticians.

Loayza, N. V. (2016). Informality in the Process of Development and Growth. World bank Policy Research Working Paper 7858. 


\section{MODERNIZING THE MONETARY POLICY FRAMEWORK IN COMOROS ${ }^{1}$}

The Comorian monetary policy framework is currently the subject of detailed modernization proposals. IMF technical assistance missions have helped to define an Action Plan which the central bank intends to implement soon. This paper sets out how the modernization plans will address the problem of weak monetary policy transmission in the face of underlying structural excess liquidity. It outlines the constraints in the existing financial system, including the absence of a functioning interbank market and existing central bank capacity which need to be addressed before proceeding with plans to issue central bank bills. The issuance of bills while increasing sources of collateral for the banking system is unlikely to mitigate the high level of structural excess liquidity, which will require additional structural measures to improve private sector access to credit.

\section{A. Introduction}

\section{Comoros operates a conventional peg arrangement within a monetary policy}

cooperation agreement with France. This simultaneously pegs the Comorian Franc to the Euro and anchors fiscal policy through the ceiling on statutory advances from the Banque Centrale des Comores $(\mathrm{BCC})$ to the treasury based on the average of internal revenue over the previous three years. ${ }^{2}$ Central bank reserves are currently well above the requirements mandated by the monetary policy agreement with France. The authorities are planning to modernize the monetary policy framework to improve the transmission of monetary policy which is currently severely impaired by the lack of instruments to deal with a persistent underlying excess liquidity (chart). Even if it serves to bolster the stability of the financial

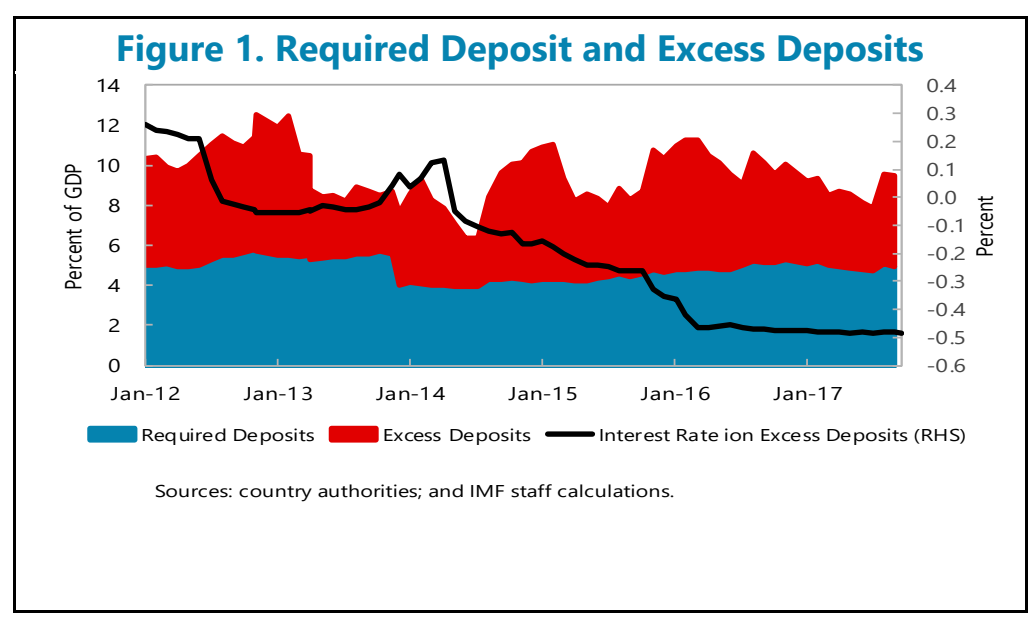

\footnotetext{
1 Prepared by Liam O'Sullivan. This chapter has benefited from comments and inputs from various departments at the $B C C$, and several IMF colleagues.

2 In 1979, Comoros signed a monetary cooperation agreement with France, making the Comoros part of the franc zone which also includes the CFA franc zone (the West African Economic and Monetary Union (WAEMU) and the Central African Economic and Monetary Union (CEMAC) where the CFA franc is used). The monetary regime is similar to that of the CFA franc zone, with the following principles (i) the French Treasury guarantees without limits the convertibility of the franc zone; (ii) the currencies are convertible at a fixed exchange into Euro (before French francs); and (iii) the zone members must pool together a minimum of 50 percent of their international reserves, corresponding to 20 percent of the monetary base of each central bank, into an operations account at the French Treasury. The exchange rate of the Comorian franc to the French franc (now euro) has differed from that for the CFA franc since 1994.
} 
system, there is nonetheless an ongoing concern that the persistently high degree of excess liquidity may be reducing the efficiency of monetary policy transmission and limiting credit to the private sector.

\section{Improving monetary policy transmission requires strategies based on TA} recommendations to address structural excess liquidity. Financial institutions prefer to hold deposits at the BCC greater than the required 15 percent ratio, despite a 7 to 14 percent spread available from lending to the private sector. Approximately 13 percent of excess reserves are in foreign currency and held by nonresidents. Structural excess liquidity weakens the transmission of money supply variations (through, for example, an increase in BCC deposits) to private sector credit compared to other countries. The key issue is whether central bank bill issuance would contribute to reducing the structural excess liquidity phenomenon in a manner that would result in increased credit to the private sector.

3. The purpose of this paper is therefore twofold: to examine how the proposals for modernizing the monetary policy framework will improve the transmission of monetary policy and to assess their impact on the excess liquidity. The paper is divided into 4 sections. The first section describes in broad terms the existing monetary policy framework. The following two sections outline the various proposals for modernizing the framework and the prior conditions for successfully launching BCC bills. The final section draws some initial conclusions and makes recommendations regarding the timing and sequencing of the modernization process.

\section{B. The Existing Monetary Policy Framework}

\section{A cooperation agreement between the Zone Franc countries provides for a guarantee} of the CFA franc's peg to the euro and its convertibility. ${ }^{3}$ The guaranteed convertibility is in principle unlimited, and operates through drawings on the BCC's "operations account" at the French Treasury. The agreement and related foreign exchange regulations also provide for the obligation for the BCC to maintain at least 50 percent of its international reserves on the operations account and for its international reserves to represent at least 20 percent of its liabilities. With a fixed exchange rate and limited capital mobility, the monetary policy objective for the authorities consists of ensuring that there are adequate reserves to maintain the peg although with strict capital controls in place, there is in theory scope for an independent monetary policy.

5. The only monetary policy instrument currently effectively available to the BCC is reserve requirements. These reserves are calculated conventionally at 15 percent of customer deposits in banks and other financial institutions and are remunerated at the Eonia rate less 1.25 points. Excess bank reserves at the BCC are paid interest at Eonia less 0.125 . The interest paid by the BCC for compulsory and surplus reserves is currently zero because the EONIA rate is negative. Hence a second monetary policy tool - the remuneration on obligatory and excess financial institution

\footnotetext{
3 The parity, in effect since the 1994 devaluation, is KMF 493 per euro. The institutional background is described in Gulde and Tsangarides (eds., 2008).
} 
deposits - is effectively unavailable. Although the official texts mention a discount rate, no technical or legal description allows for the actual use of this mechanism. None of the rates applicable are in any case reviewed in line with prevailing macroeconomic conditions.

\section{At close to 6 percent of GDP, the excess reserves of the financial institutions present a} challenge to the implementation of monetary policy. The risk aversion of the commercial banks has resulted in lower rates of growth of private sector credit than are needed to boost the economy's flagging growth performance (left panel). Compared to international standards, the level of excess liquidity in Comoros is high (right panel) if not exceptionally so ${ }^{4}$; it indicates nevertheless a need to address the underlying issues in the financial sector. Moreover, in the absence of daily accounting data, the BCC is not currently equipped to make forecasts of bank liquidity which severely limits the operational scope for monetary policy.

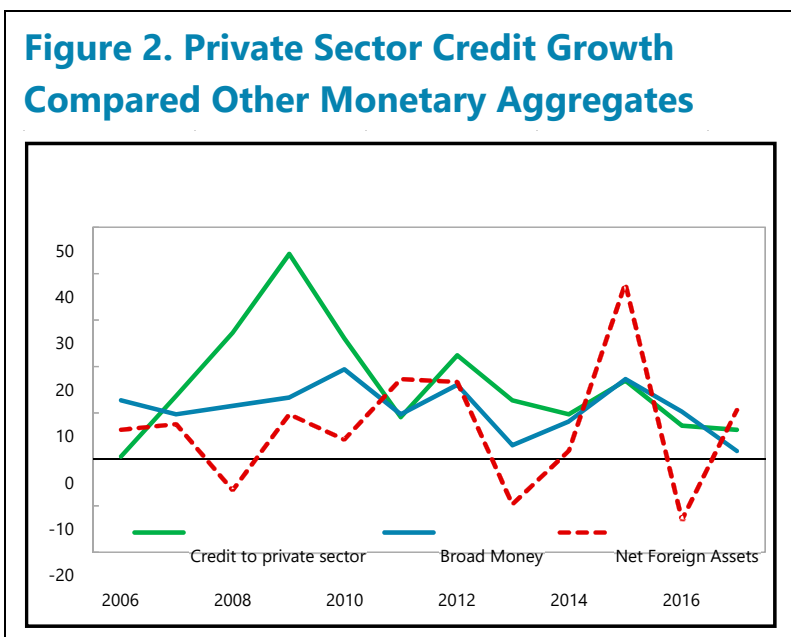

Figure 3. Excess Reserves in percent of GDP

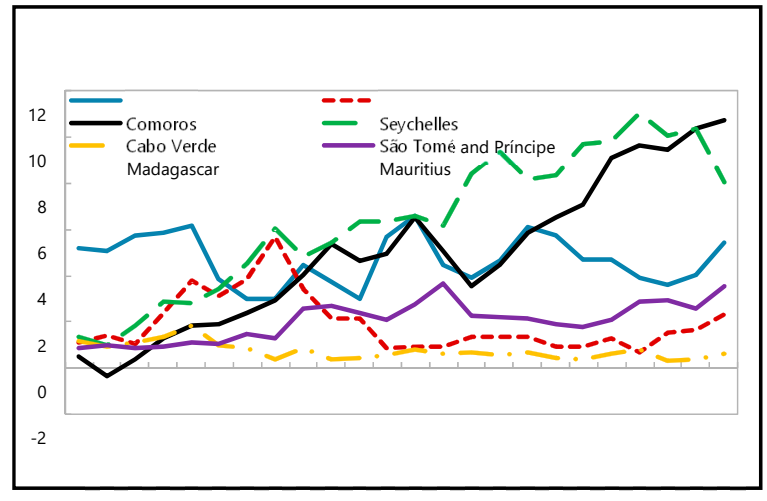

Sources: country authorities; and IMF staff calculations.

\section{The Proposal to Modernize the Monetary Policy Framework}

7. The purpose of the reform proposal is to improve the transmission of monetary policy. Developing financial intermediation by active management by the Central Bank of bank liquidity volume and amount of excess liquidity - can influence the cost of credit and the attractiveness of deposits. It is the monetary policy equivalent of the trend towards enhancing the role of price signals in the economy in general. In low-income, economies, the signals given by the Central Bank are not easily transmitted for two reasons, both of which are relevant to Comoros. First, the capital market is

\footnotetext{
${ }^{4}$ The sharp increase in level of excess reserves in Cabo Verde and Sao Tome and Principe since 2015 is due to increasing risk aversion on the part of commercial banks in response to high levels of non-performing loans (as well as exceptional levels of migrant deposits in the case of (abo Verde).
} 
less efficient, and in addition the excess liquidity of the system limits the sensitivity of the institutions to changes in interest rates.

\section{The objective of the proposed modernization of monetary policy instruments is to} provide the BCC with more effective tools to manage bank liquidity, without compromising the parity arrangement of the Comorian franc vis-a-vis the euro. In implementing the proposals, it is critical to take the local context fully into account. For example, the number of establishments subject to reserve requirements, while having grown significantly in recent years, remains quite low (8 credit institutions) and both the BCC and the financial institutions have relatively few staff. Taking account of the capacity constraints, it is likely that the modernization project will take some time to implement and it is advisable in any case that it be carried out progressively to allow sufficient time for all actors to adapt to the proposed changes.

\section{The first stage of the reform involves creating the capacity for the BCC to produce} bank liquidity forecasts. This is an urgent task specific to the central bank as a result of having sole access to information on the past and future evolution of autonomous factors determining bank liquidity because they are recorded in the balance sheet of the Central Bank. In this respect, the modernization plans are progressing well: the BCC has already created a forecasting unit and is preparing the legal texts for the establishment of the Monetary Policy Committee and other institutional requirements for the reform although it will take some time for bank liquidity forecasts to be developed because there is a learning process involved and daily accounting is also required.

10. The reform also aims at the introduction of an interest rate corridor defined by the rates applicable at the standing facilities of the BCC. These rates will define the limit on variations in the interest rate on short-term interbank lending organized within this corridor. The standing facilities will consist of an automatic deposit facility offering a dissuasive return: bankers should prefer to have a remunerative asset or lend to their colleagues rather than depositing their cash account with the BCC and a lending facility, also at dissuasive rates to encourage bankers to borrow from another commercial bank rather than the central bank. Thus, begins the operation of the interbank market. When an interbank loan has been made, banks will systematically inform the BCC and the data on the interest rates applicable will be a valuable indication of the state of bank liquidity as felt by the institutions involved. It is also the beginning of a short rate curve. The BCC will have to ensure the collection of the relevant data on these rates as well as their diffusion on its site.

\section{The issuance of bills by the BCC is intended to meet two objectives: to absorb excess} bank liquidity and to provide collateral for loans between the BCC and between banks. At the same time as the issuance of bills begins, interest payments on excess reserves will be suppressed so as to create incentives for financial institutions to purchase bills. In view of its monetary policy objective, the issuance of bills will be exclusively reserved for institutions receiving deposits and subject to reserve requirements, with a view to ensuring operational feasibility for the BCC although eventually, this faculty could be open to other financial institutions. The main steps in the process of modernizing the monetary policy framework and their current status are summarized in the Table 1 underneath. 
Table 1. Comoros: Implementation Steps for Modernization of the Monetary Policy Framework

\begin{tabular}{|l|l|l|}
\hline \multicolumn{1}{|c|}{ Actions } & \multicolumn{1}{|c|}{ Objectives } & Status March 2018 \\
\hline $\begin{array}{l}\text { Create a BCC Monetary } \\
\text { Policy Committee }\end{array}$ & $\begin{array}{l}\text { Take monetary policy decisions based on } \\
\text { an assessment of national and } \\
\text { international macroeconomic conditions, } \\
\text { particularly as regards setting the key } \\
\text { interest rates of the BCC. }\end{array}$ & $\begin{array}{l}\text { Draft legal text } \\
\text { prepared }\end{array}$ \\
\hline $\begin{array}{l}\text { Create a Liquidity } \\
\text { Management Committee }\end{array}$ & $\begin{array}{l}\text { Assist the Governor in decision-making } \\
\text { processes, notably regarding the volume } \\
\text { of adjudications. }\end{array}$ & $\begin{array}{l}\text { Draft legal text } \\
\text { prepared }\end{array}$ \\
\hline $\begin{array}{l}\text { Put in place the legal and } \\
\text { regulatory framework for } \\
\text { BCC bills }\end{array}$ & $\begin{array}{l}\text { Define the characteristics of bills and the } \\
\text { conditions for issuance and subscription. }\end{array}$ & $\begin{array}{l}\text { Draft legal text } \\
\text { prepared }\end{array}$ \\
\hline $\begin{array}{l}\text { Put in place the legal and } \\
\text { regulatory framework for } \\
\text { purchase and sale of CBB } \\
\text { bills: repurchase } \\
\text { agreements and framework } \\
\text { contract for banks and } \\
\text { other financial } \\
\text { establishments }\end{array}$ & $\begin{array}{l}\text { Allows holders of bills to sell at any given } \\
\text { time. }\end{array}$ & $\begin{array}{l}\text { Draft legal text } \\
\text { prepared }\end{array}$ \\
\hline $\begin{array}{l}\text { Create a standing loan } \\
\text { facility at fixed interest rates } \\
\text { relative to the rate on CBB } \\
\text { bills }\end{array}$ & $\begin{array}{l}\text { Facilitates the absorption of liquidity } \\
\text { shocks at the level of individual financial } \\
\text { institutions, enabling them to meet } \\
\text { reserve requirement obligations. }\end{array}$ & $\begin{array}{l}\text { Legal text to be } \\
\text { drafted }\end{array}$ \\
\hline
\end{tabular}

12. The reform proposals will therefore fundamentally change the operation of the monetary policy framework and the transmission of monetary policy. To summarize, the change is intended to operate in 4 main ways.

- The system will now be anchored on the monetary policy rate decided by the monetary policy committee. In principle the policy rate will be indexed to the money market rate of the anchor zone.

- The structure of interest rates will be determined by the interest rate corridor.

- Interest rates on private sector credit and deposits will reflect rates prevailing in the interbank market. 
- The BCC will aim to manage liquidity through issuance of bills and in so doing create an importance source of collateral for the banking system.

\section{Sequencing Reforms and Preconditions for BCC Bill Issuance}

13. Before deciding to proceed with bill issuance, there are a number of preconditions to be met and the monetary authorities should therefore ensure that reforms are undertaken in the appropriate sequence. Key requirements in this regard are the following.

- a sound and competitive financial system is in place including an effective electronic payments system and interbank market;

- the central bank has a sufficient degree of institutional autonomy and operational capacity; and

- the central bank has sufficient liquidity forecasting capacity.

14. Each of the requirements mentioned above poses challenges in the Comorian context. First, the financial system is currently under considerable stress with high levels of non-performing loans and considerable excess liquidity. Currently, the National Payment System does not have the necessary infrastructure to facilitate electronic funds transfers between credit institutions and other financial institutions, or to facilitate electronic payments - a prerequisite for a functioning interbank market-at the end-user (retail) level. Second, an efficient accounting and auditing system is also a requirement for ensuring that transactions are recorded appropriately and accurately, which is crucial for providing credible and timely information that allows markets to make sound decisions. In addition, more specific to monetary policy implementation, weak payment systems or central bank accounting frameworks can greatly complicate the implementation of a liquidity management and forecasting framework and, ultimately, jeopardize the central bank's ability to control its balance sheet. Finally, weaknesses in the functioning of the judicial system are also a source of uncertainty, in particular regarding the use of collateral. All of these deficiencies need be addressed for financial intermediation to expand.

15. Successful implementation of money market operations also depends on the establishment of a sound financial relationship between the central bank and the government. International experience suggests that one of the main challenges during the transition to reliance on money market operations relates to curtailing the ability of the government to rely on the direct credit of the central bank. In the Comorian context, this issue is addressed via the limit on statutory advances to the government by the BCC. To avoid the possibility that the issuance of bills becomes a source of direct financing for the government, measures should be considered to reinforce the existing regulations regarding direct financing to define the limit on statutory advances to the Treasury are adequate for the purpose.

16. The $B C C$ is not equipped to make forecasts of bank liquidity. The production by the $B C C$ of bank liquidity forecasts should be developed as a priority because it involves a learning process. While the recent steps towards establishing the Liquidity Management Committee at the BCC are 
welcome, without progress on developing a daily accounting position, the BCC cannot analyze past developments or make forecasts of bank liquidity.

17. In terms of its impact on the transmission of monetary policy, the issuance of BCC bonds while mopping up excess liquidity in the system will represent a safe investment for commercial banks and divert credit from the private sector. The issuance of CBN bills in that sense will not address the underlying cause of excess liquidity which seems to be a function of structural factors such as the absence of adequate collateral and the ability of the judicial system to enforce contracts. Improving the transmission of the monetary policy by addressing the issue of private sector access to credit will therefore require specific reform measures to improve the legal framework governing commercial bank lending, particularly as regards enhancing the structure of loan guarantees and building on the establishment of the Risk Information Centre (see Selected Issues chapter on Financial Sector Risks and the effectiveness of Monetary Policy).

\section{E. Conclusions}

18. The purpose of the proposed modernization of the Comorian monetary policy framework is to improve the transmission of monetary policy. This can be accomplished in the following sequence. The surrounding infrastructure for the upgrade of the monetary policy framework is already in place with the establishment of the Monetary Policy Committee and the Liquidity Management Committee. The same is true for the standing facilities which will define the interest rate corridor for the operation of the interbank market. By putting in place the interbank market in this way, the transmission of monetary policy will already be improved as price signaling will be initiated in the operation of the banking system. In terms of sequencing, prior to proceeding with the issuance of BCC bills there is also a need to ensure that adequate payment systems are in place, the financial system is sound and liquidity forecasting is adequate. Further technical assistance is available on all of these areas from the IMF and the World Bank (as well as from the BCEAO and Rwanda). Addressing the underlying problem of excess liquidity however will require additional structural measures. 


\section{References}

Gray, S., \& Talbot, N. (2006). "Bank of England Handbooks in Central Banking No. 24 - Monetary Operations.

Gray, S., \& Pongsaparn, R. (2015). Issuance of Central Bank Securities: International Experiences and Guidelines, IMF Working Paper (IMF/15/106).

Gulde, A.M., \& Tsangarides, C.G. (eds., 2008). Common Currency, Uncommon Challenges.

Laurens, B., \& Al. (2005). Monetary Policy Implementation at Different Stages of Market Development.

International Monetary Fund (2015). Evolving Monetary Policy Frameworks in Low Income and Other Developing Economies. Staff Report. 


\section{FINANCIAL SECTOR RISKS AND MONETARY POLICY EFFECTIVENESS ${ }^{1}$}

This note updates and extends previous work on financial sector risks in Comoros (see IMF Country Report 16/394 - Selected Issues). It analyzes the key contours of financial sector risk in Comoros, also vis-à-vis comparators in Sub-Saharan Africa (SSA), and how these have shifted since the last analysis. The overall picture of financial health is mixed. Comorian banks remained well - capitalized and liquid since end-2015, while provisioning slipped, NPLs persisted at elevated levels, and aggregate profitability remained stagnant. These features are also borne out by the cross-country comparison with comparators in Sub-Saharan Africa. But the financial health outlook is heterogeneous across institutions, with large NPL portfolios well provisioned-for and concentrated in less systemicallyimportant institutions, interbank linkages that are small in economic size and limit potential financial system contagion, and variable profitability across institutions. Implications of financial sector fragility for the effectiveness of monetary policy are also explored and recommendations for improving policy effectiveness are developed.

\section{A. Background and Macroeconomic Context}

1. Comoros faced continued macroeconomic challenges in 2017 (Figure 1). Largely on the back of an improved electricity supply throughout the year and favorable external sector developments, growth in 2017 increased moderately to 2.7 percent. Inflation dipped to 1 percent on average for the year, chiefly reflecting lower import prices. Fiscal policy execution remained challenging, particularly with stagnant tax revenues that fell well short of the authorities' ambitious budgetary targets.

\section{Comoros' macroeconomic challenges also impacted upon the financial sector (Figure}

2). In the face of the above macroeconomic headwinds, the downward trend in private sector credit growth of recent years continued in 2017. This was due in the main to the sustained elevated level of NPLs and the associated difficulties in recovering doubtful loans, which increased financial
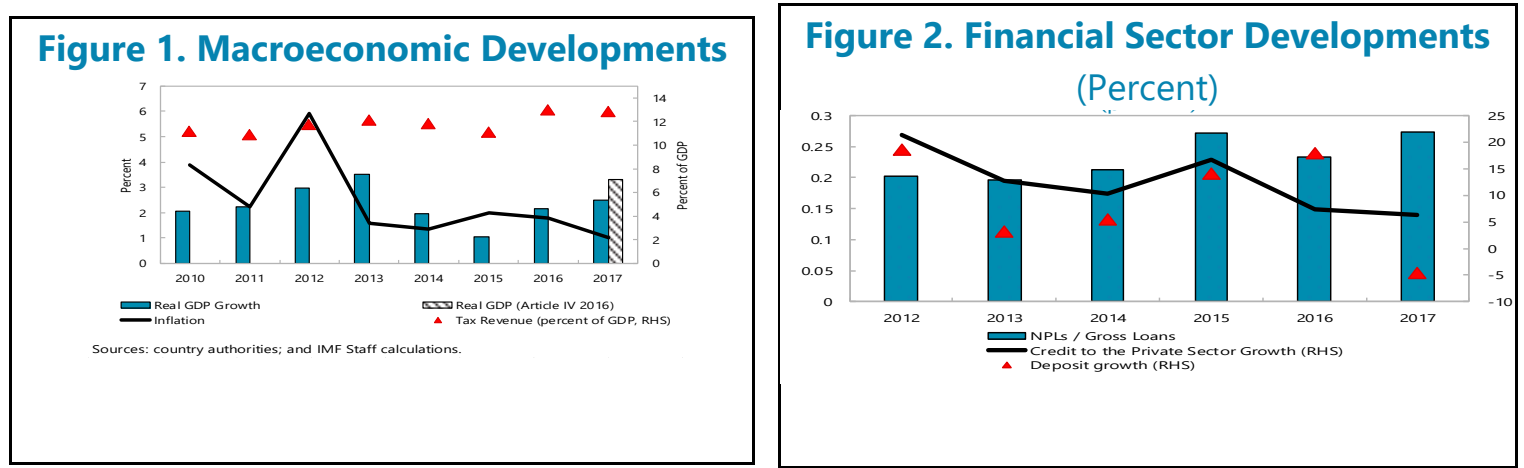

institutions' lending risk. Meanwhile, the

\footnotetext{
${ }^{1}$ Prepared by Ibrahim Ahamada, Michel Bua, and Cameron McLoughlin, with excellent support from Mounir Bari. The chapter benefited from extensive comments from the BCC and several IMF colleagues.
} 
government borrowed from a financial institution

(KMF 3bn / about 1 percent of GDP) to help finance its expenditure needs. Also, deposit growth faltered, after strong expansions in the deposit base in previous years associated with one-off factors (budget support, telecommunications license payment), while isolated liquidity tensions emerged amidst some governance problems.

3. Against this backdrop, this paper analyses three key issues. First, the key risk features of the Comorian financial sector and their changes over time are analyzed, also within an SSA context. Second, a preliminary empirical analysis explores the implications of financial sector fragility and risks in Comoros for monetary policy effectiveness. Third, recommendations for improving financial sector health and the efficacy of monetary policy in Comoros are developed.

\section{B. Stylized Facts—Financial Sector Fragility and Risks}

4. The Comorian financial system is mildly concentrated and composed of eight deposittaking and lending institutions, including microfinance networks and foreign-owned banks. The activities of the four commercial banks operating in Comoros are complimented by three microfinance institutions, as well as by the systemically-important (about one-fifth of system-wide deposits) state-owned postal bank (SNPSF). Microfinance institutions are particularly prominent in rural areas and on the smaller islands (Anjouan, Mohéli). The three largest financial institutions control 60 percent of system-wide assets. At present, three banks are foreign-owned, although the ownership structure of the sector is currently in flux.

\section{Most financial institutions engage in traditional banking activities, are subject to the} same prudential requirements, and with one exception to the same taxation laws. Two banks and one microfinance institution accept only gold as collateral. Illustrating collateral quality problems in the economy, the microfinance institution that only lends against gold experienced the jointfastest loan book growth in 2017. With one exception - a microfinance network that is the most profitable financial institution in the country - all financial institutions make significant tax contributions to the state coffers (0.8 percent of total tax revenues in 2017).

\section{Responsibility for financial sector supervision lies with the BCC, supported also by} technical assistance from the Fund and other partners, although the Ministry of Finance has some influence on system regulation. The financial sector surveillance unit (DSBR) of the BCC is responsible for financial sector supervision and enforcement of prudential norms and regulations. The supervisor closely monitors financial sector institutions through and intensive program of on-site and off-site inspections, also sanctioning institutions when they are found to be in violation of prudential regulations. The DSBR also continues to benefit from an extensive program of Fundsupported technical assistance, particularly regarding risk-based supervision, receiving also assistance from the French prudential regulator (ACP). The Ministry of Finance has a limited influence on the financial system, through the administration of interest rates (see below) and directions given to state-owned enterprises about where to place deposits. 


\section{An examination of changes in financial soundness indicators since the last exercise} presents a mixed picture (Figure 3, upper panel). Comorian financial institutions remained wellcapitalized and liquid over the period 2015 - 2017. But provisioning decreased and NPLs remained high at almost a quarter of the total loan portfolio. This, combined with a slippage in the rate of provisioning, left the balance sheet exposed to an NPL write-down. ${ }^{2}$ Profitability remained stagnant.

\section{The health of the Comorian financial sector is heterogeneous across financial} institutions (Figure 3, lower panel and Table 1). The spread of financial soundness indicators around the sector-wide indicator is noticeable, reflecting the differing degree of financial health between institutions. Some fare relatively poorly on as few as 2 or 3 indicators, whilst others are experiencing issues in multiple areas.

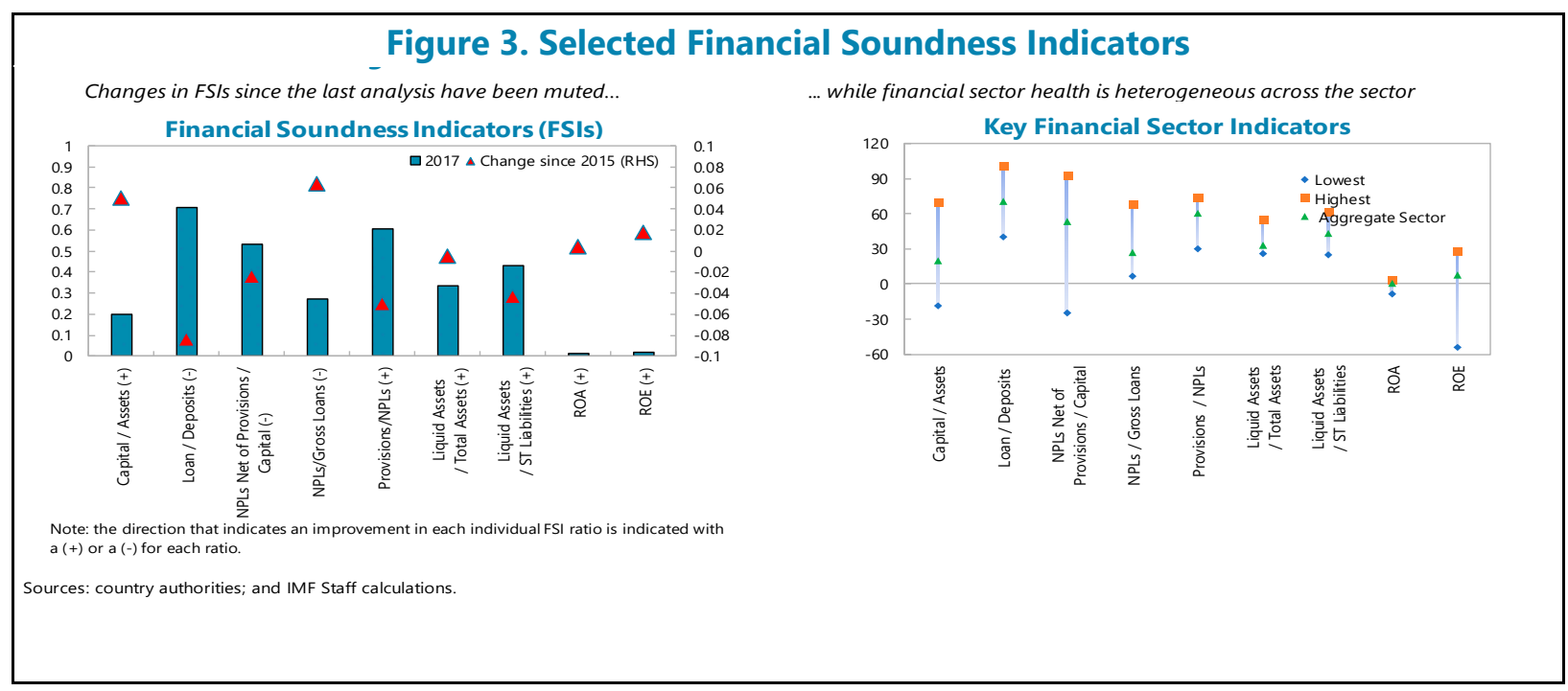

\begin{tabular}{|llllllll}
\hline \multicolumn{1}{|c|}{ Table 1. Comoros: FSI Heatmap 2017} & & \\
\hline
\end{tabular}

\footnotetext{
${ }^{2}$ A write-off of all unprovisioned NPLs would consume about half of system-wide capital.
} 


\section{Exposure to unprovisioned NPLs is an ongoing concern, but heterogeneity matters}

(Figure 4). Measured on a sector-wide basis, unprovisioned NPLs rose compared to previous years. A more granular analysis reveals that smaller financial institutions (measured by assets / total assets) tend to have larger non-performing loan portfolios. One exception is a systemically-important institution (about one-fifth of system-wide assets), one-third of whose loan book is non-performing. Fortunately, provisioning rates in the institutions with larger NPL portfolios tend to be higher.

10. Comoros' persistently high NPL stock reflects two main factors. First, it includes a considerable proportion of legacy loans that turned sour during the vanilla sector crisis of the early 2000s and remain unresolved, along with other bad loans that are yet to be written-off by holding institutions. Second, a few well-connected debtors in Comoros' undiversified economic structure account for the vast proportion of the NPL stock. Recovery of these doubtful loans is particularly difficult in the absence of both specialized financial courts and rigorous enforcement of judicial decisions. Nevertheless, the authorities expect that a regulation that mandates the better classification, provisioning and write-off of loans, with a compliance date of end-2018, will see the NPL ratio drop considerably by this date, particularly with resolution of legacy vanilla sector loans. There is no concrete evidence that feedback effects to NPLs from government arrears to domestic suppliers are a major factor in Comoros. ${ }^{3}$

\section{Lending continued to non-productive economic sectors in 2017, with new NPLs} reflecting this trend (Figure 5). As in 2015, commerce and households continued to be the two economic sectors to which the greatest proportion of new credit was extended in 2017. New NPLS in 2017 also followed this pattern. These trends reflect the lack of bankable projects in Comoros outside of the import business.

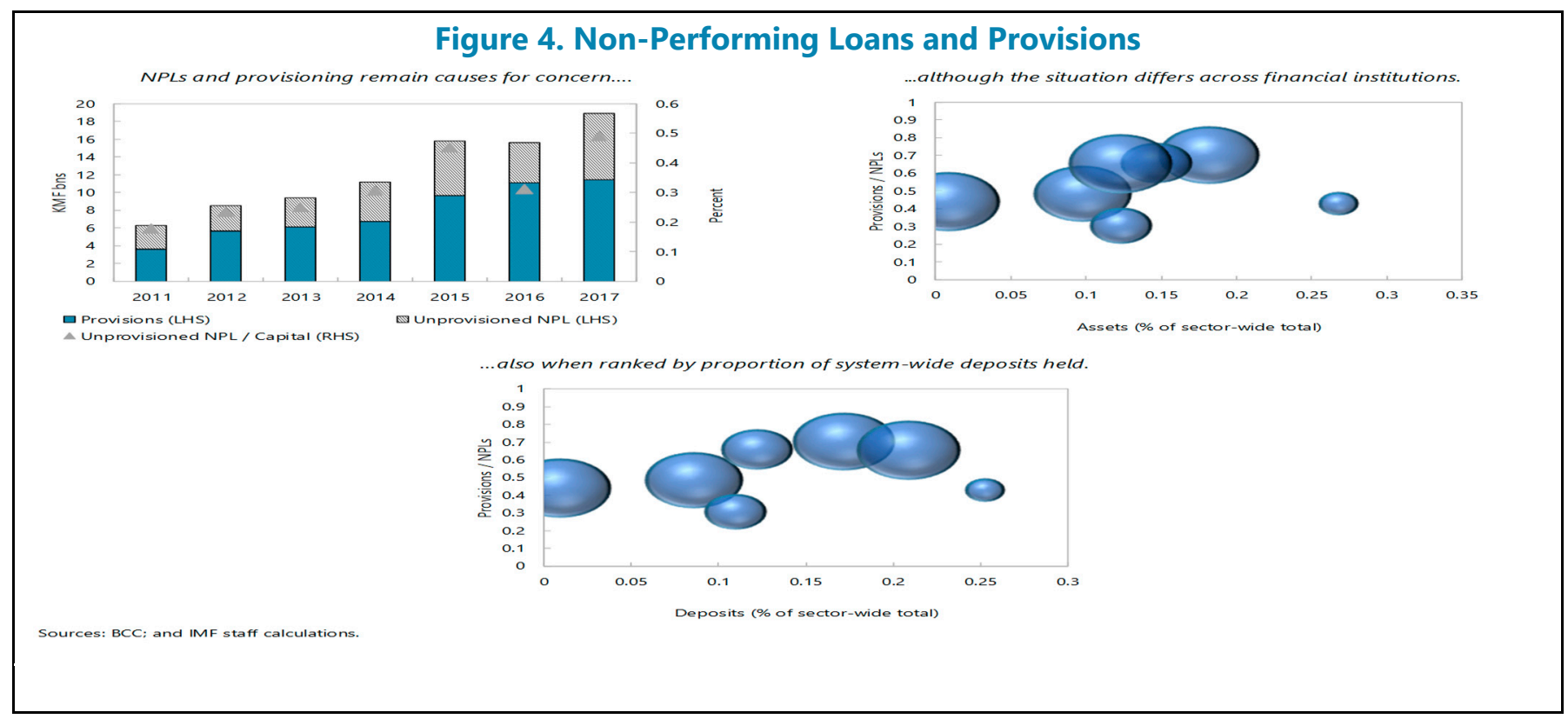

\footnotetext{
${ }^{3}$ The latest data on government arrears to the private sector date from June 2013 and are not available by sector.
} 


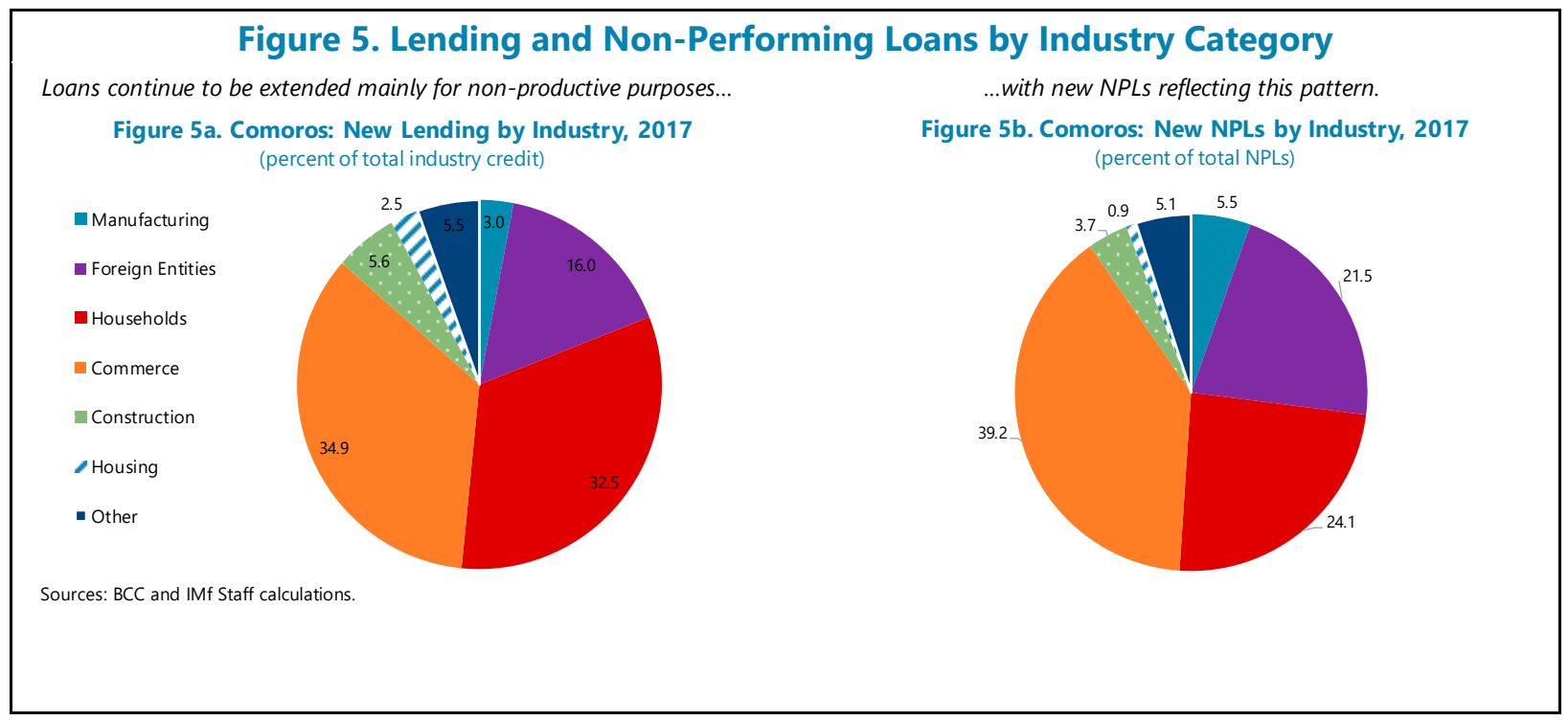

12. In the Comorian financial system, inter - institution linkages are limited and small in economic size, but two banks hold significant proportions of total inter-institution deposit holdings. Commercial banks hold deposits of other resident commercial banks and microfinance institutions, while microfinance institutions themselves hold neither. Reflecting the underdeveloped nature of the Comorian financial system, total inter - institution deposits only amount to about 1.5 percent of GDP. However, these deposits are highly concentrated, with two banks together holding over 90 percent of deposits from other banks, and over 65 percent of deposits from microfinance institutions.

\section{The limited nature of inter-institution linkages means that the difficulties of the} systemically-important SNPSF and the associated fiscal risks to the State's balance sheet persist, although 2017 saw the welcome first steps in implementing the authorities' recovery plan for the institution. SNPSF, which offers both traditional banking and postal activities, is solelyowned by the State, which is therefore obliged to backstop the institution in tough times. Despite that SNPSF has faced major operational difficulties for many years, it continues to attract about onefifth of system-wide deposits (chiefly civil servant salaries and SOE deposits). The latest-available estimates indicate that to make SNPSF fully-functional, an injection of about KMF 10.4bn / 3.7 percent of GDP / 22 percent of government revenues would be needed. ${ }^{4}$ In 2017, the authorities implemented the first tranche of their three-year rescue plan, using funds from the BCC statutory advance facility. Whilst further adequate funding for the rescue plan is still to be identified, limited financial sector linkages would limit the possible contagion of any financial stress it may experience in the meantime.

\footnotetext{
${ }^{4}$ This figure may be higher once an ongoing accounting audit of the institution's books is completed. The audit had an original target deadline of $20^{\text {th }}$ April, which has since been surpassed.
} 
14. A cross-country analysis reveals that the relatively well-capitalized and liquid Comorian financial sector is however in some respects more fragile than that of comparator countries

(Figure 6). The financial sector in Comoros is well-capitalized and highly liquid, compared to the peer group average in Sub-Saharan Africa (SSA). ${ }^{5}$ However, the loan portfolio is of relatively poor quality, and the sector is relatively more-exposed to unprovisioned non-performing loans. Aggregate profitability, measured by both return on assets (ROA) and return on equity (ROE), is much lower than in comparator countries, but in Comoros this result appears to be chiefly driven by two outlier institutions.

Figure 6. Cross-Country Comparison of Selected Financial Soundness Indicators 2016

Comorian banks are relatively well capitalized...

Regulatory Capital / Risk-Weighted Assets (percent)

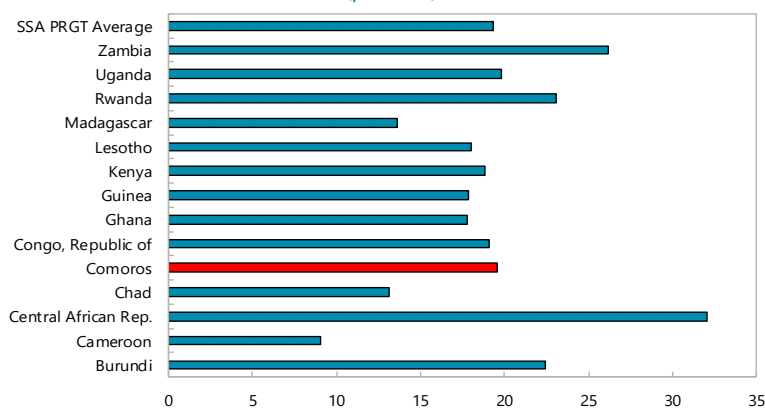

The loan portfolio is of relatively poor quality....

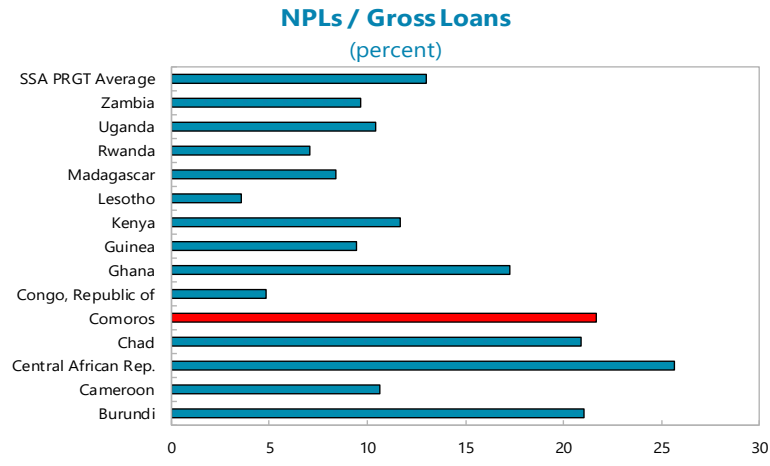

....as well as comparatively liquid.

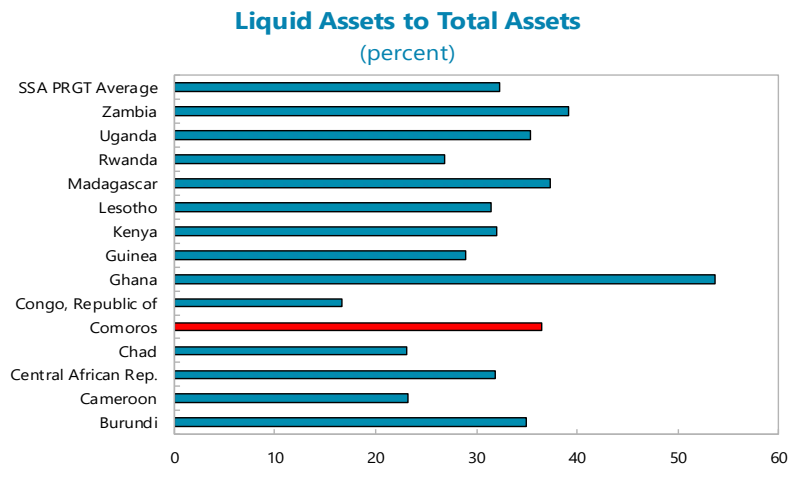

... and the balance sheet is more-exposed to un-provisioned

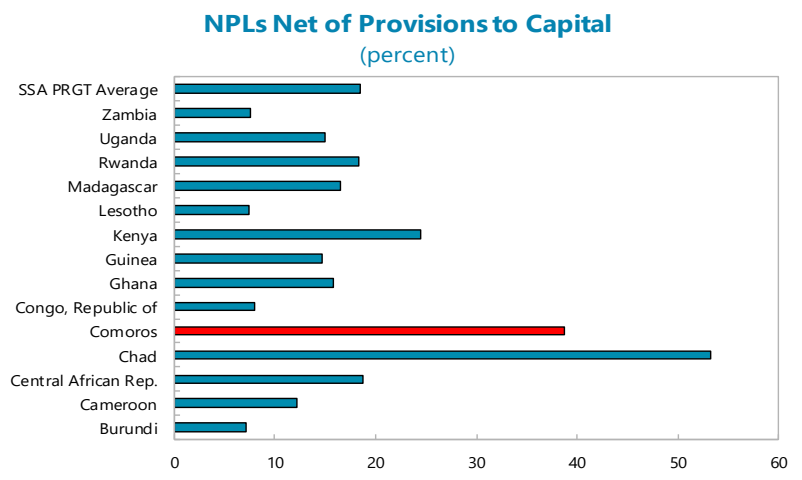

Sources: Country authorities, IMF Staff Calculations.

Note: PRGT-eligible countries included are Burundi, Cameroon, CAR, Chad, Ghana, Guinea, Kenya, Lesotho, Madagascar, Rwanda, Uganda, Zambia

${ }^{5}$ The peer group comprises PRGT-eligible countries in SSA for which data are available (Burundi, Cameroon, Central African Republic, Chad, Comoros, Republic of Congo, Ghana, Guinea, Kenya, Lesotho, Madagascar, Rwanda, Uganda and Zambia). 
Figure 6. Cross-Country Comparison of Selected Financial Soundness Indicators (Concluded)

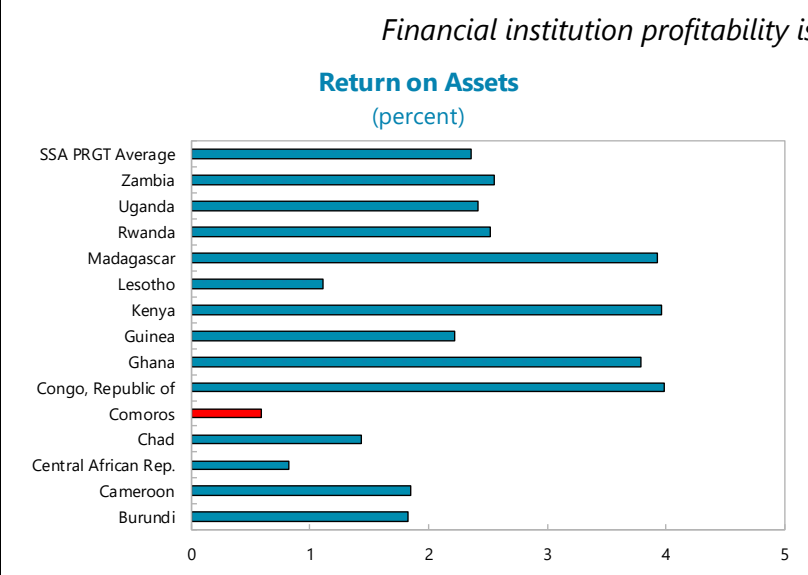

lagging that of comparator countries

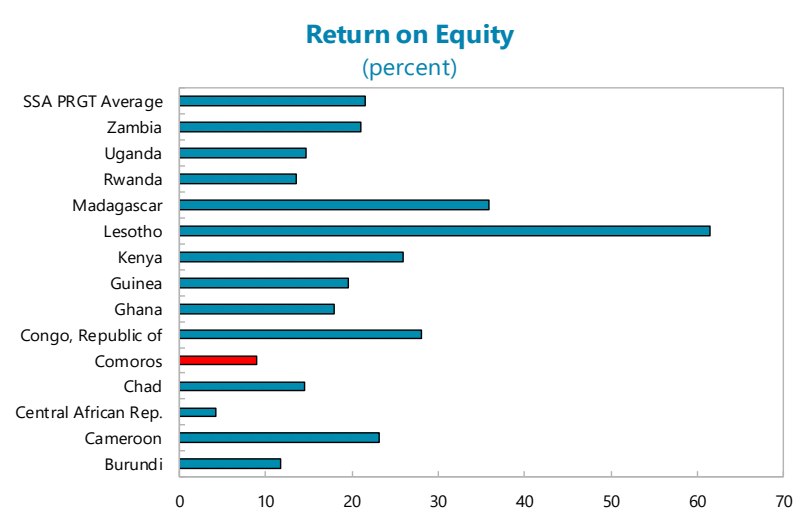

Interest earnings are comparatively high...

....as are overhead costs.
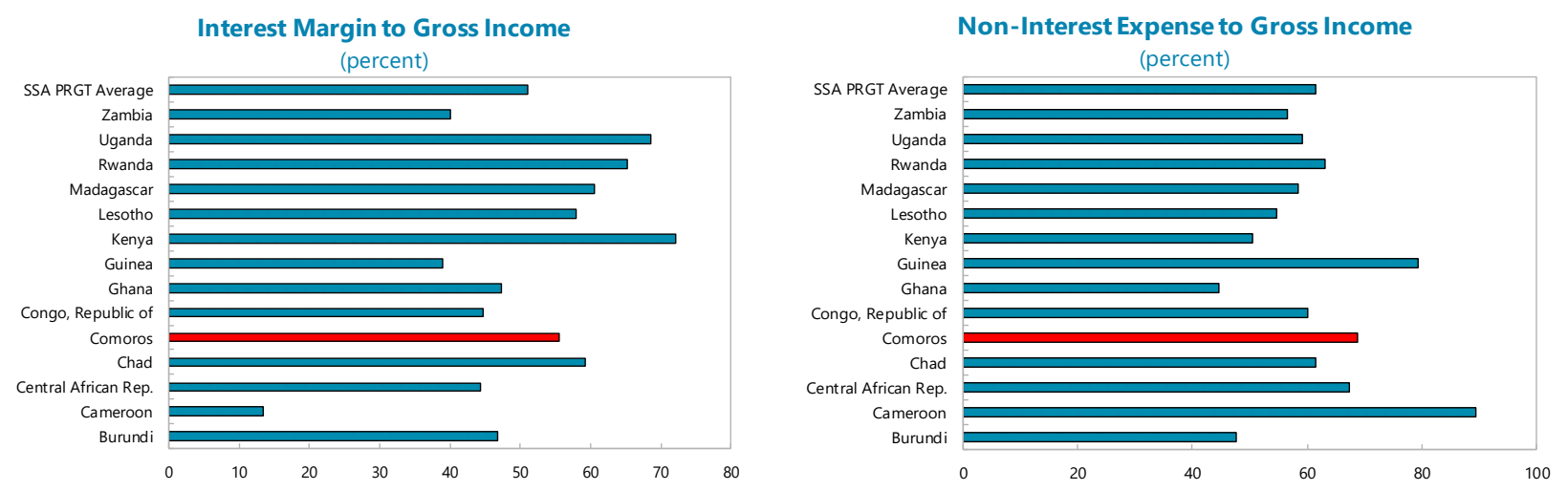

Sources: Country authorities, IMF Staff Calculations.

Note: PRGT-eligible countries included are Burundi, Cameroon, CAR, Chad, Ghana, Guinea, Kenya, Lesotho, Madagascar, Rwanda, Uganda, Zambia.

\section{Financial Sector Health and Monetary Policy}

15. How effective are monetary policy tools in the context of the above-described macrofinancial developments and financial sector fragilities? As noted above, credit growth has slowed in recent years, while excess liquidity has persisted. To what extent are the available monetary policy tools useful in the context of high NPLs, and what is the impact of monetary policy on credit to the economy hence economic growth in this context? 
16. In the context of the monetary cooperation agreement with France that regulates country's fixed exchange rate with the Euro, the Central Bank of the Comoros (BCC) possesses two main monetary policy tools. These are (i) the level of statutory reserve requirements, and (ii) the remuneration on obligatory and excess financial institution deposits. ${ }^{6}$ Since January 2014 , the statutory reserve requirement has been fixed at 15 percent of financial institution deposits (versus 20 percent before this date). The interest rates available on statutory and excess reserves are both linked to the Eurozone Overnight Index Average (EONIA). The interest rate on obligatory reserves is calculated by the formula EONIA - 1.25 percent, and EONIA - 0.125 percent for the remuneration on excess reserves. Due to the very low level of Eurozone interest rates in recent years, the BCC decided to apply a zero rate to statutory and obligatory reserves when the adjusted EONIA rate results in a negative interest rate. This has been the case since August 2012.

\section{The administered corridor for financial institution lending to the private sector is} significantly higher than the zero-remuneration available on financial institution deposits at the central bank. The Ministry of Finance, on the advice of the BCC, has set the lending rate corridor between a minimum 7 and a cap of14 percent. Deposit rates at financial institutions are also administered, with a floor of 1.75 percent. $^{7}$

18. A variety of factors, chiefly lender risk aversion, limited economic diversification and a shortage of bankable projects, restricted investment opportunities in the context of an underveloped financial system, as well as foreign exchange flows, contribute to excess liquidity in Comoros. Despite the significant spread available through lending to the private sector, financial institutions prefer to hold unremunerated deposits at the BCC that are well in excess of the statutory requirement, rather than lend these funds. Financial institutions thereby eschew high potential returns from lending to

Figure 7. Financial System and Interest Rates

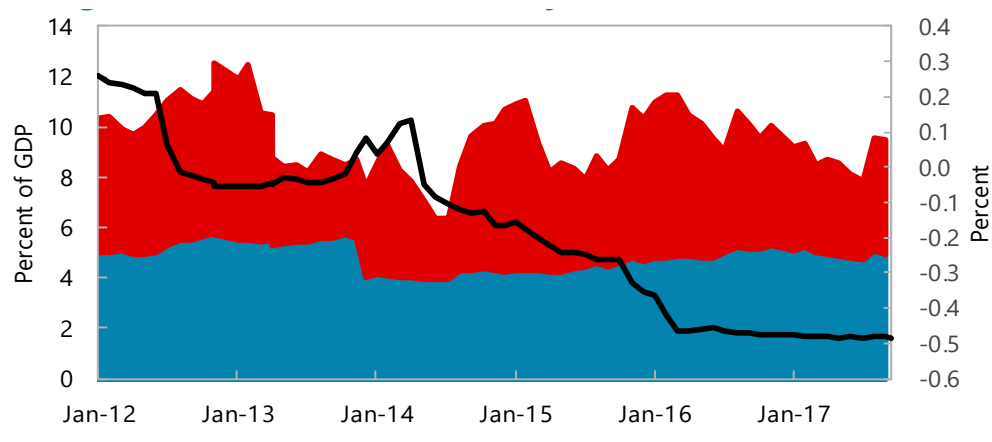

Excess Deposits Required Deposits $ـ$ Interest Rate ion Excess Deposits (RHS Sources: country authorities; and IMF staff calculations. the private sector, preferring to remain prudent and reticent to lend. Anecdotal evidence suggests that in the face of poor collateral, risk aversion is so high that this would be the case even if lending rates were substantially higher than the mandated 14 percent ceiling. Furthermore, a shortage of bankable projects in the

\footnotetext{
${ }^{6}$ The BCC has other interest rates (e.g. the discount rate, calculated at EONIA + 1.5 percent), but which are less operational (e.g. due to lower interbank financing needs in a situation of structural excess liquidity).

7 See Annex for a summary of interest rates applied in the Comorian economy.
} 
undiversified private sector, as well as underdeveloped financial markets leave banks with few alternative investment opportunities. These factors, along with foreign currency flows (for example significant inbound remittance flows), contribute to structural excess liquidity that has been at least equal to, and often greater than (expressed as a percentage of GDP), the magnitude of required reserves (Figure 7 ). This structural excess liquidity weakens the monetary policy transmission mechanism and the ability of BCC to influence demand in the economy.

\section{In Comoros, sterilization tools - the usual policy approach for managing excess} liquidity - are in the developmental phase, but it is unlikely that these will address the structural issues underlying the phenomenon. The BCC plans to introduce central bank bills in July 2018 to manage structural excess liquidity (see Selected Issues chapter on Modernizing the Monetary Policy Framework). Apart from the potential costs of sterilization (effect on central bank income, weakening of the central bank balance sheet, these tools are unlikely to address the poor quality of bank balance sheets and the associated lender risk aversion, which are a major contributor to structural excess liquidity in Comoros.

\section{Preliminary empirical analysis suggests that monetary policy effectiveness in} influencing credit growth depends on the quality of bank balance sheets, highlighting the effects of lender risk aversion on financial institution credit provision. An empirical model is used to analyze the strength of the relationship between the (lagged) BCC policy rate and credit to the private sector depending on the level of loan provisioning (used as a proxy for balance sheet quality). ${ }^{8}$ Results show that during the period prior to August 2012 (when the BCC policy rate was positive), the strength of the negative association between the (lagged) BCC policy rate and credit to the private sector (controlling for the \$US / KMF exchange rate and a time trend) in the case of highquality balance sheets (low provisioning was about six times as strong than in the case of high loan provisioning. After August 2012, the estimated trend in private sector credit is lower in the high provisioning case, than in the low-provisioning case. These results highlight that above a certain threshold, lender risk aversion is so high (due to difficulties in recovering doubtful loans) that financial institutions are reluctant to lend to the private sector. Instead, they prefer to park their funds with the central bank and receive zero interest, contributing to structural excess liquidity.

\section{Conclusions and Policy Recommendations}

21. The above analysis shows that while the Comorian financial system suffers from some persistent vulnerabilities, there are some ameliorating factors. The persistently high NPL level and provisioning levels are worrisome, while faltering deposit growth, ongoing governance issues and isolated liquidity tensions demonstrate that the financial system operates under continued duress. On the positive side however, the sector remains broadly well-capitalized and liquid and, with large NPL portfolios confined to less systemically important financial institutions, interbank linkages

\footnotetext{
${ }^{8}$ The same results obtain when using NPLs as the threshold variable upon which the strength of the relationship between the BCC policy rate and credit depends, albeit with fewer available observations. Two lags of the policy rate variable are used in the model to avoid endogeneity concerns.
} 
that are small in economic size, and profitability that at a more granular level is not as stagnant as aggregate indicators would suggest.

\section{Financial sector weaknesses hamper monetary policy effectiveness in the context of} structural excess liquidity. In particular, low-quality loan portfolios heighten lender risk aversion and reduce financial institutions' willingness to lend. This, combined with a shortage of bankable private-sector projects and underdeveloped financial markets induces structural excess liquidity and weakens the transmission mechanism between monetary policy and private sector credit.

\section{To address financial sector fragilities, the BCC should continue to closely monitor} financial institutions to address any further emerging problems. Rigorously implementing a regulation that provides for the better classification of, provisioning for, and write-off of loans by end-2018 should reduce the NPL level to a more-acceptable level (assuming that more loans are not reclassified as doubtful in the process of applying the regulation). This is because most of the legacy NPLs from the vanilla sector, along with other NPLs, will likely have been written-off by this time. In the meantime, the authorities should continue to closely monitor financial institutions to ensure that liquidity tensions do not reemerge.

\section{Improving monetary policy effectiveness and encouraging private sector lending will} require a more comprehensive policy approach involving all stakeholders. The $B C C$ plans to convene a meeting of all relevant stakeholders (Ministry of Finance, BCC, private sector, banks) in order to find an integrated solution to the question of boosting financing to the economy. An essential component of such an integrated strategy is an effort to address structural excess liquidity through reducing lender risk aversion. This could for example be achieved through improving the quality of lending collateral and guarantees, as well as enhancing the prospects of loan recoverability in the context of a more effective judicial system. However, better judicial decision enforcement will not be easy in the Comorian context of a small island state with tight-knit social relations. Implementing central bank bills, while a welcome step towards enhance financial sector development, should be considered as a liquidity management tool, rather than as addressing the root cause of structural excess liquidity (see Selected Issues chapter on Modernizing the Monetary Policy Framework for further details). 


\section{Annex. Interest Rates in the Comorian Economy}

\begin{tabular}{|c|c|c|}
\hline Type of Interest Rate & Rate & Comments \\
\hline Statutory reserves & $\begin{array}{c}\text { EONIA - } 1.25 \text { percent } \\
\text { Today : } 0 \%\end{array}$ & Since January 2009 \\
\hline Excess Reserves & $\begin{array}{c}\text { EONIA }-0.125 \text { percent } \\
\text { Today: } 0 \%\end{array}$ & Since January 2006 \\
\hline $\begin{array}{l}\text { BCC Statutory Advance } \\
\text { Facility }\end{array}$ & $\begin{array}{c}\text { EONIA + } 1.5 \text { percent } \\
\text { June } 2017: 1.14 \text { percent }\end{array}$ & Since 1st January 2000 \\
\hline BCC Discount Rate & $\begin{array}{c}\text { EONIA + } 1.5 \text { percent } \\
\text { June } 2017: 1.14 \text { percent }\end{array}$ & Since 1st January 2000 \\
\hline Pénalité réserves obligatoires & $\begin{array}{c}\text { EONIA + } 2 \text { percent } \\
\text { June } 2017: 1.64 \text { percent }\end{array}$ & Since 1st January 2000 \\
\hline $\begin{array}{l}\text { Remuneration of Foreign } \\
\text { exchange reserves by the } \\
\text { French Treasury }\end{array}$ & $\begin{array}{l}\text { Rate of the ECB marginal } \\
\text { facility, with a minimum of } \\
2.5 \text { percent }\end{array}$ & 1979 \\
\hline $\begin{array}{l}\text { Administrative banking } \\
\text { sector lending rate }\end{array}$ & $\begin{array}{c}\text { Range between } 7 \text { and } 14 \\
\text { percent }\end{array}$ & $\begin{array}{l}\text { Decision of the Minister of } \\
\text { Finance, } 1^{\text {st }} \text { July } 2009\end{array}$ \\
\hline $\begin{array}{l}\text { Administrative banking } \\
\text { sector savings rate }\end{array}$ & Minimum of 1.75 percent & $\begin{array}{l}\text { Decision of the Minister of } \\
\text { Finance, } 1^{\text {st }} \text { July } 2009\end{array}$ \\
\hline
\end{tabular}

